\title{
PERFORMANCES OF A TURBOCHARGED E100 ENGINE WITH DIRECT INJECTION AND VARIABLE VALVE ACTUATION
}

\author{
Alberto A. Boretti \\ School of Science and Engineering, University of Ballarat, Ballarat, VIC, Australia
}

Copyright $\odot 2010$ SAE International

\begin{abstract}
Current flexi fuel gasoline and ethanol engines have brake efficiencies generally lower than a dedicated gasoline engines because of the constraints to accommodate a variable mixture of the two fuels. Considering ethanol has a few advantages with reference to gasoline, namely the higher octane number and the larger heat of vaporization, the paper explores the potentials of dedicated pure ethanol engines using the most advanced techniques available for gasoline engines, specifically direct injection, turbo charging and variable valve actuation. Computations are performed with state-of-the-art, well validated, engine and vehicle performance simulations packages, generally accepted to produce accurate results targeting major trends in engine developments. The higher compression ratio and the higher boost permitted by ethanol allows larger top brake efficiencies than gasoline, while variable valve actuation produces small penalties in efficiency changing the load. Finally, small, high power density, turbo charged, direct injection, variable valve actuation load controlled engines are proved to operate very efficiently over driving cycles.
\end{abstract}

\section{INTRODUCTION}

Ethanol is an alternative fuel resulting in less greenhouse gas (GHG) emissions than gasoline [1]. The key environmental benefit of ethanol is that, unlike gasoline and diesel, its consumption does not significantly raise atmospheric levels of $\mathrm{CO}_{2}$. This is because the $\mathrm{CO}_{2}$ which is released during the burning of the fuel is counter-balanced by that which is removed from the environment by photosynthesis when growing crops and trees for ethanol production. There is considerable controversy as to whether corn-based ethanol is a net positive with respect to GHG emission. Production of ethanol fuel from sugar cane is however generally accepted to produce a reduction in GHG emission. On a life cycle basis, ethanol produced today roughly reduces $20 \% \mathrm{GHG}$ emissions [1], and in terms of fossil energy, it delivers one third or more energy than is used to produce it when accounting for the energy contained in the co-products [1]. This GHG emission reduction could increase with improved efficiency and use of renewable energy, and producing ethanol from more abundant cellulosic biomass sources rather than corn or sugar cane. If ethanol has the potential to significantly reduce global GHG emissions associated with transportation, controls are definitely needed to protect ecologically important lands and the production efficiency and environmentally friendliness has to be incontestably improved as well.

Ethanol blends in use today have little impact on fuel economy or vehicle performance. Ethanol is available in various blends, most commonly E5, E10, E85, E100, where the E stands for ethanol and the number denotes the approximate \% of ethanol. Ethanol delivers less energy per litre than gasoline, but has an increased resistance to knock. Most modern gasoline vehicles may be fuelled with gasoline blended with small amounts of ethanol, gasoline, E10 or any mixture of the two, with no perceptible effect on fuel economy. Flex-fuel vehicles may be fuelled with both gasoline and ethanol in any proportions. Hardware modifications needed include more durable valves and valve seats, and the use of ethanol-compatible materials in the fuel system. Today's flex-fuel vehicles can run on E85, gasoline or any mixture of the two, with automatic fuel adjustments of engine operation [2]. E85 has a much higher octane rating than gasoline, and turbocharged flexi-fuel engines [2] may use higher boost pressure and more advanced ignition timing than on gasoline without risk of knocking or pre-detonation. The compression ratio of the engine however cannot be increased above the value needed when running gasoline, and further benefits in terms of reduction of $\mathrm{CO}_{2}$ production and use of fossil fuels may therefore be obtained running the higher compression ratio pure ethanol engines that are the subject of the paper, where direct injection is added to turbo charging to fully exploit the advantages of ethanol's higher research octane number and higher heat of vaporization.

Pure ethanol engines are not a new idea. They have been very popular in Brazil in the 80s. Brazil has been the pioneering country in the use of ethanol as a road transport fuel, starting its experience in between the two world wars. Sugar cane has been one of the main resources of Brazil since the 1500s, and sugar cane crops are the basis for ethanol production in Brazil. In the 70s, increased oil prices convinced the Brazilian government to launch the "Pro-alcohol" program to help reduce the country's dependence on oil replacing gasoline with ethanol made from sugar. In the early $80 \mathrm{~s}$ almost all cars sold in Brazil ran on ethanol. As oil prices dropped in the latest 80 s, the Brazilian government suddenly decreased support for ethanol production, and production volumes stagnated despite the fact 
that demand remained strong. A serious supply crisis occurred in 1989, when drivers where not able to find the pure ethanol fuel required to run their not flex-fuel cars. The supply crisis and the subsequent loss of consumer's confidence in pure ethanol fuelled cars plus the oil prices affordable over again plunged the popularity of ethanol-powered cars. When oil prices returned high, ethanol in Brazil rebounded, but this time car manufacturers designed flex-fuel cars powered by any mixture of gasoline and ethanol, allowing the driver to choose whichever fuel was cheaper or more easily available.

The additional benefits in terms of reduction of $\mathrm{CO}_{2}$ production and use of fossil fuels and a more mature, environmentally friendly and sustainable ethanol industry may now renew the scope of pure ethanol engines having efficiencies much better than gasoline.

Figure $1 \mathrm{a}$ and $1 \mathrm{~b}$ presents fuel economy and carbon dioxide production data of Diesel and gasoline passenger cars vs. displacement of the engine (from [36]). Carbon dioxide production is assumed to be equal to $2632 \mathrm{~g} /$ litre for Diesel fuel, $2331 \mathrm{~g}$ litre for Petrol. A climate change and road safety conscious society can not afford to use very inefficient engines in large passenger cars for just having power and torque outputs well in excess of what is allowed to use by speed limits $(110 \mathrm{~km} / \mathrm{h}$ on highway and $50 \mathrm{~km} / \mathrm{h}$ within populated areas in Victoria). Aim of the paper is therefore to define a spark ignition engine for ethanol that may be closer to Diesel than a standard gasoline for full load and part load efficiencies running stoichiometric, but having higher speed and power density than Diesel for downsizing.

Diesel lean diffusion combustion is efficient but it does not allow running high engine speeds, and leaner combustion is associated with smaller power densities. Therefore, there is space to develop competitive stoichiometric spark ignition solutions. And when reference is made to Diesel, ethanol is a much more environmentally friendly solution because of the upstream cancellation of the climate change effects.

The paper explores the advantages direct injection and high turbo charging may give to pure ethanol engines fully exploiting the reduced knock tendency and the increased heat of vaporization of ethanol when compared to gasoline. Computations are performed with state-of-the-art, well validated, engine and vehicle performance simulations packages, generally accepted to produce accurate results targeting major trends in engine developments. The paper presents basic features of a dedicated E100 engine, plus details of engine and vehicle models, and results of simulations including engine brake specific fuel consumption map and Full size passenger car fuel economy covering the new European driving cycle. Aim of the paper is to provide two computational assessments.

First, a small high power density, turbo charged, direct injection, variable valve actuation load controlled engine optimized for E100 (pure ethanol) may run higher compression ratios and boost pressures and use better spark advances than same engine optimized for G100 (pure gasoline) thanks to the larger octane number and heat of vaporization of E100, providing better fuel conversion efficiencies. Second, small displacement, high power density, turbo charged, direct injection, variable valve actuation load controlled engines optimized for E100 or G100 may operate during driving cycles much more efficiently than large displacement, low power density, naturally aspirated, port fuel injection, throttle controlled E100 or G100 engine thanks to the much better part load efficiency for same instantaneous brake torque and speed of the engine, providing much better fuel energy usage.

First task starts from two validated WAVE [22] engine performance models, one for a 2L turbo charged, direct injection Diesel engine and one for a $4 \mathrm{~L}$ naturally aspirated, port fuel injection, throttle controlled G100 engine, with computed brake efficiencies and specific fuel consumptions vs. engine speed and brake mean effective pressure within a $5 \%$ of measured values.

The Diesel engine has an intercooler, waste gate turbine and cooled exhaust gas recirculation. This engine is then modified to run E100 and G100 with a reduced displacement of 1.6L, replacement of the centrally located Diesel direct injector with a centrally located gasoline direct injector and spark plug, reduced compression ratio and addition of variable valve actuation modules on the intake valves to control the load throttle less. These changes that could be extremely costly on a real engine just require a few modification of the model to obtain computed brake efficiencies and specific fuel consumptions vs. engine speed and brake mean effective pressure that are expected to be not that far from actual values.

Second task starts from a validated Lotus [30] vehicle simulation model for a Full size passenger car equipped with the 4L naturally aspirated, port fuel injection, throttle controlled G100 engine, with computed fuel economies over the new European driving cycle within a $5 \%$ of measured values. The vehicle model is then modified to use the brake specific fuel consumption maps of the $1.6 \mathrm{~L}$ high power density, turbo charged, direct injection, variable valve actuation load controlled engine optimized for E100. These changes that could be extremely costly on a real vehicle just require a few modification of the model to obtain fuel economies that are expected to be not that far from actual values. 


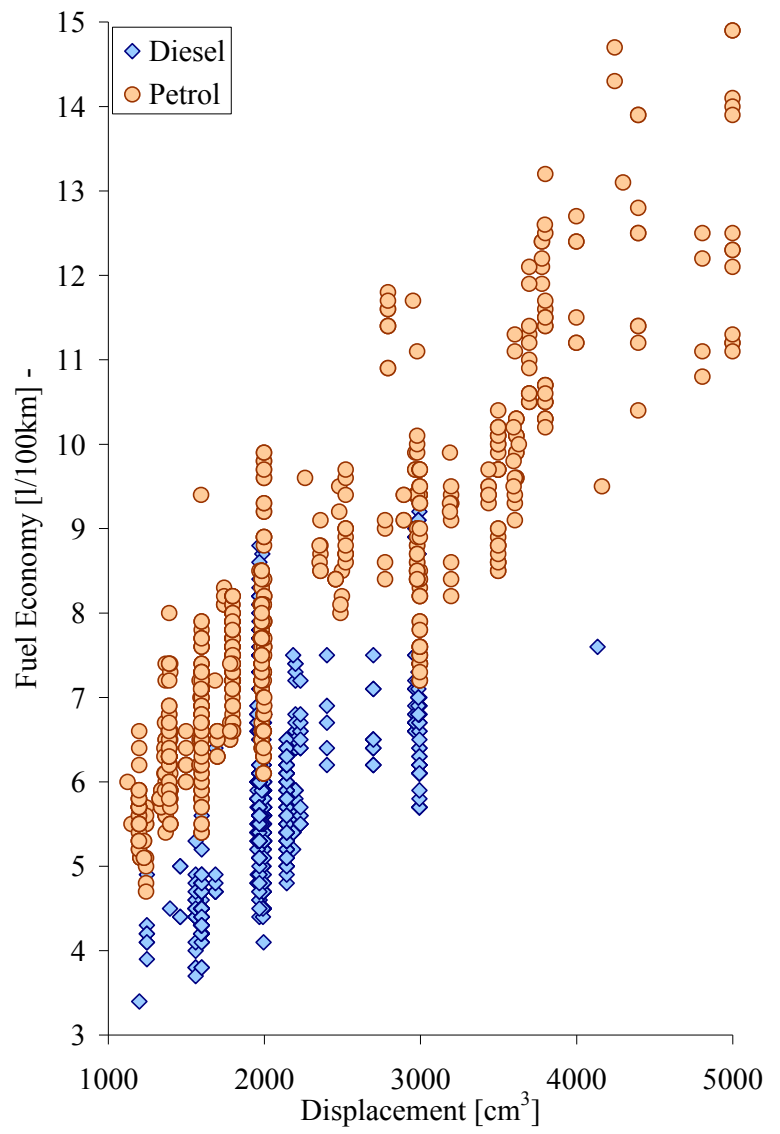

Figure 1a - Fuel consumption (in litres/100 km) vs. displacement (in $\mathrm{cm}^{3}$ ) for 2010 passenger cars Euro 5 .

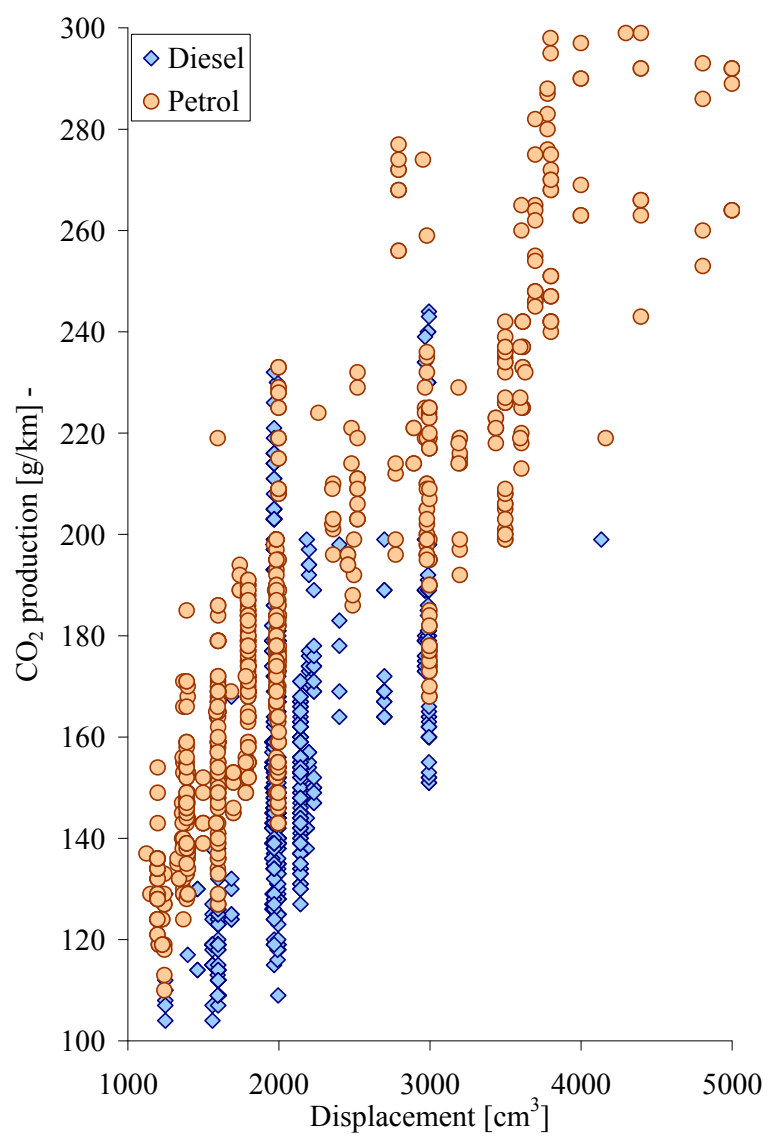

Figure $1 \mathrm{~b}-\mathrm{CO}_{2}$ production (in $\mathrm{g} / \mathrm{km}$ ) vs. displacement (in $\mathrm{cm}^{3}$ ) for 2010 passenger cars Euro 5 . 


\section{HIGH POWER DENSITY AND EFFICIENCY SPARK IGNITION ENGINE}

The most part of gasoline engines now in production are naturally aspirated, port fuel injected, throttle controlled, stoichiometric engines with three ways catalytic after treatment with major advantage the low cost of production. The major weaknesses of these engines are not only the low top brake efficiency, generally below 35\%, but mainly the large penalties in efficiency reducing the load due to throttling, with efficiencies about 15\% during operation at 1 bar Brake Mean Effective Pressure (BMEP) and 1,500 rpm.

Figures $2 \mathrm{a}$ and $2 \mathrm{~b}$ present the brake efficiency and the Brake Specific Fuel Consumption (BSFC) of a 4L, naturally aspirated gasoline engine. The compression ratio is $10.5: 1$. These are computational results obtained with a validated engine efficiency model, with differences vs. experiments done on a properly operating and well maintained engine dynamometer verified to be less than $5 \%$. The top efficiency is $35.5 \%$, corresponding to a brake specific fuel consumption of $235 \mathrm{~g} / \mathrm{kWh}$. The brake specific fuel consumption for operation at 1 bar brake mean effective pressure and 1,500 rpm is $575 \mathrm{~g} / \mathrm{kWh}$ corresponding to an efficiency of $14.5 \%$.

Figures $3 \mathrm{a}$ and $3 \mathrm{~b}$ present for comparison the brake efficiency and the brake specific fuel consumption of $1.6 \mathrm{~L}$, turbo charged, direct injected, lean burn, Diesel engine. The compression ratio is 16.5:1. These results are computational results obtained with a validated engine model, with differences vs. experiments done on a properly operating and well maintained engine dynamometer verified to be less than $5 \%$. Figures $3 \mathrm{a}$ and $3 \mathrm{~b}$ refer to a $1.6 \mathrm{~L}$ Diesel engine that is a bench mark for efficiency providing the best fuel economy of a non hybrid compact passenger car [36]. The ethanol and gasoline engines defined in the following section will be based on the parent 2L engine having much larger flow area for gas exchange and permitting the higher engine speeds following downsizing by stroke reduction.

The top efficiency is $43.5 \%$, corresponding to a brake specific fuel consumption of $194 \mathrm{~g} / \mathrm{kWh}$. The brake specific fuel consumption for operation at 1 bar brake mean effective pressure and $1,500 \mathrm{rpm}$ is $354 \mathrm{~g} / \mathrm{kWh}$ corresponding to an efficiency of $23.8 \%$. The part load benefits of the Diesel are however much more than that thanks to downsizing. To produce the same instantaneous power, the downsized Diesel engine must run not 1 , but 4/1.6=2.5 bar brake mean effective pressure. The brake specific fuel consumption for operation at 2.5 bar brake mean effective pressure and $1,500 \mathrm{rpm}$ is $280 \mathrm{~g} / \mathrm{kWh}$ corresponding to an efficiency of $30 \%$, i.e. almost three times the efficiency of the naturally aspirated $4 \mathrm{~L}$ gasoline engine.

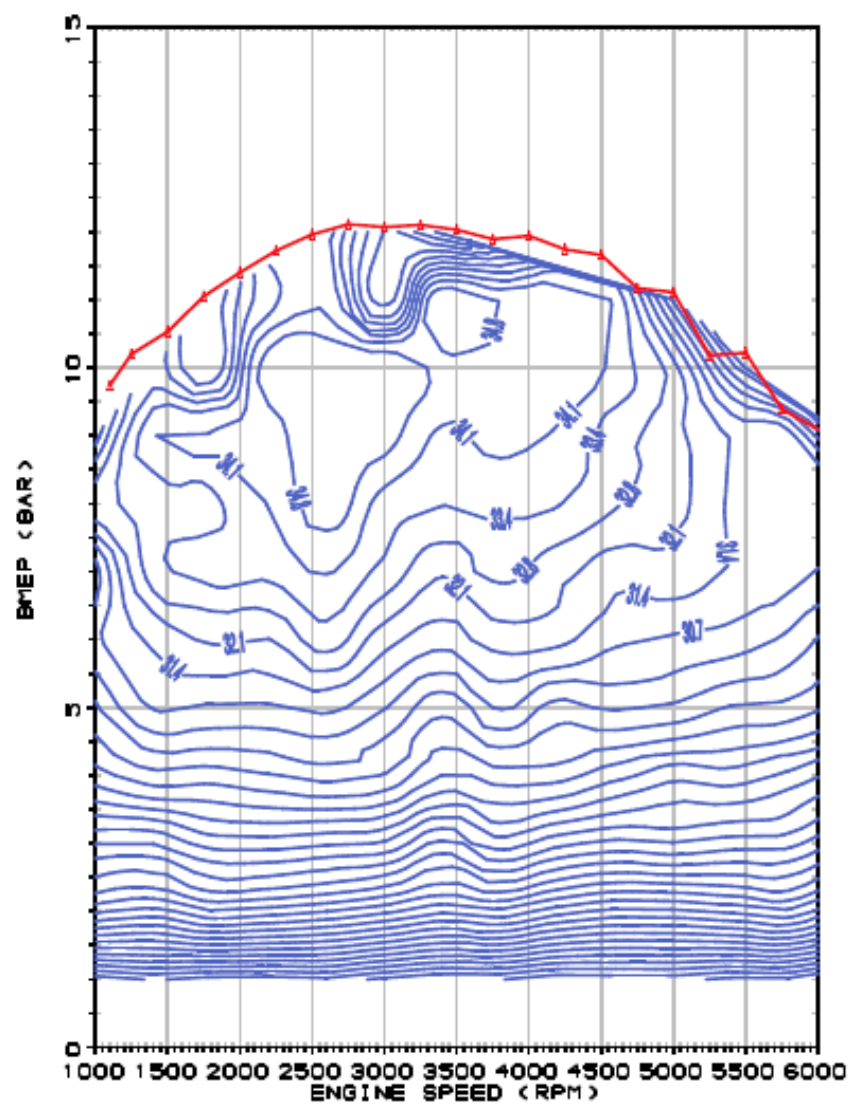

Figure $2 \mathrm{a}-$ Brake efficiency of a naturally aspirated, stoichiometric, 4L gasoline engine. 


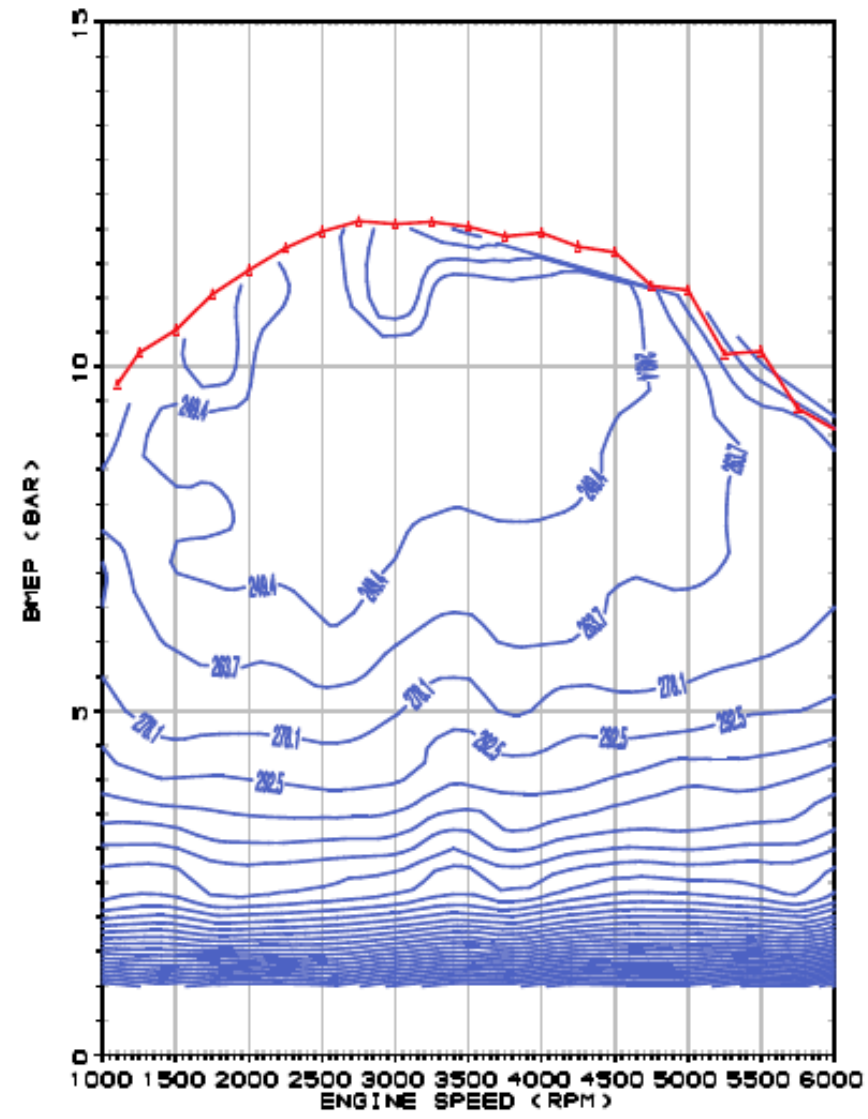

Figure $2 \mathrm{~b}-\mathrm{BSFC}(\mathrm{g} / \mathrm{kWh})$ of a naturally aspirated, stoichiometric, 4L gasoline engine.

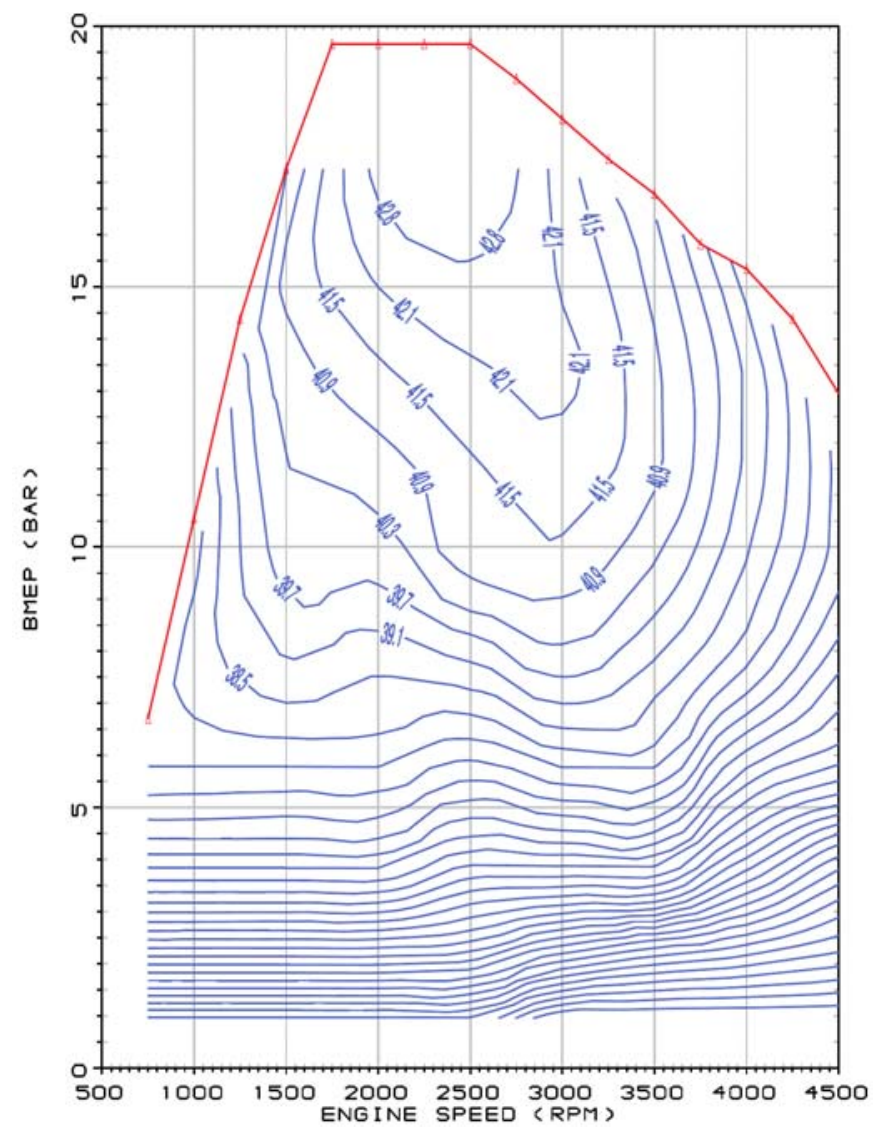

Figure $3 \mathrm{a}-$ Brake efficiency of a TDI, lean burn, and 1.6L Diesel engine. 


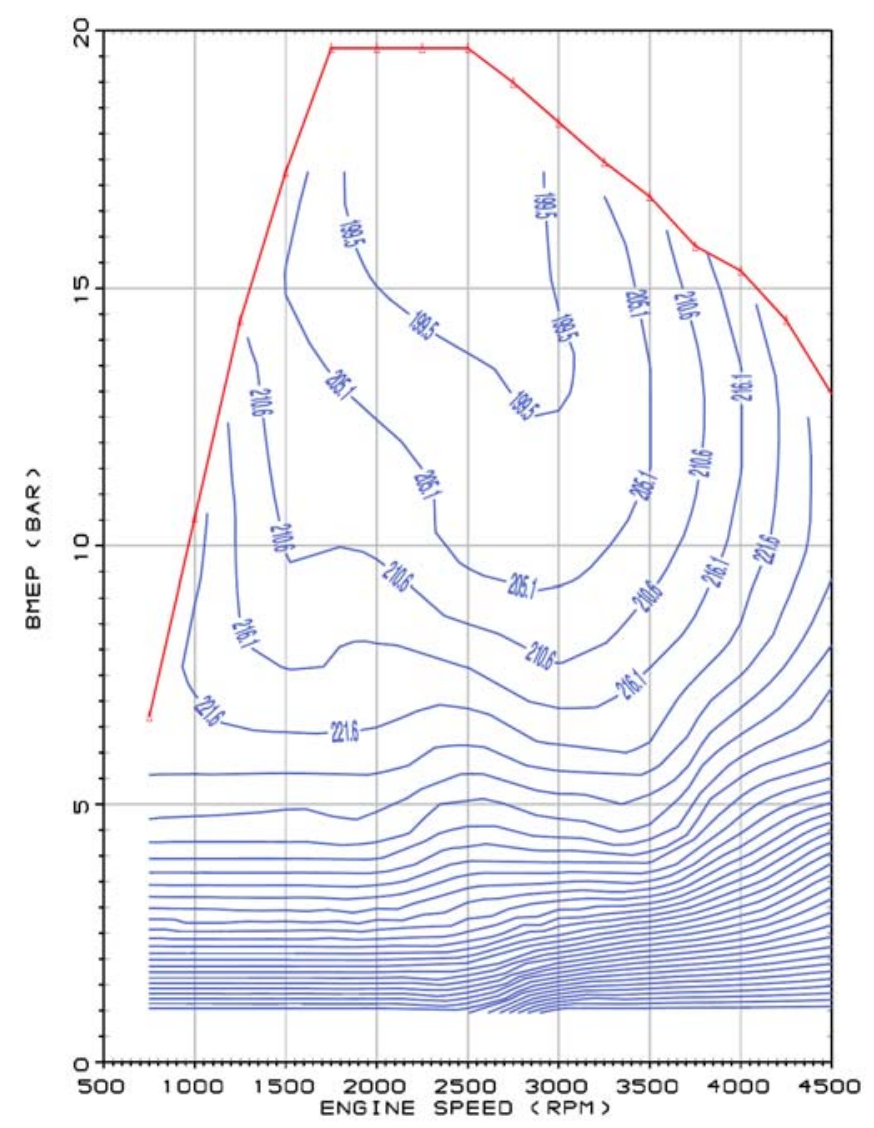

Figure $3 \mathrm{~b}-\mathrm{BSFC}(\mathrm{g} / \mathrm{kWh})$ of a TDI, lean burn, 1.6L Diesel engine.

Turbo charging, direct injection and variable valve actuation are the major areas of development of gasoline engines, while the three way catalytic after treatment still suggest the less efficient stoichiometric operation. Turbo charging permits larger specific power densities and therefore downsizing for better operation over driving cycles. Turbo charging also permits partial recovery of exhaust energy thus boosting the conversion efficiency. Direct injection permits better charging efficiencies over the range of speeds and loads (the fuel is directly injected with vales closed, and volumetric efficiency and charging efficiency are therefore synonyms) and better resistance to knock due to the in cylinder vaporization of the liquid fuel and the optimized injection timings also boosting the conversion efficiency. Variable valve actuation finally permits to control the air quantity and the swirl and tumble charge motions in the cylinder by changing the valve lift and timing of the two intake valves independently improving charging efficiency, combustion evolution and finally boosting conversion efficiency over the range of engine speeds and loads.

Turbo charging is one of the main advantages of Diesel engines, now being considered also for gasoline engine applications to improve both the power density and the fuel conversion efficiency. Although the main advantages of Diesel are high compression ratio and lean operation, turbo charges increases the power density which is otherwise low due to lean operation and offers efficiency benefits partially recovering the exhaust heat to compress the intake air. Gasoline engine turbo charging technology was specifically developed for racing applications during the so called Turbo Era in Formula One from 1977 to 1989, and it is now an area of major interest for new passenger car engines because of the benefits on vehicle economy through recovery of exhaust waste energy boosting the power density and the opportunity to run higher brake mean effective pressures thanks to downsizing during emission cycles. The turbo charged port fuel injected Formula One engines of the 80 s were able to achieve amazing specific power and torque densities, with brake mean effective pressures BMEP of more than 55 bar [3].

Downsizing and turbo charging and direct injection may be combined with electronic valve control [4] to better deal with the challenges of fuel economy enhancement. The main issue of the spark ignition engine is the pumping losses at part load due to the traditional throttle-based load control. The throttle-less spark ignition engine control systems through variable valve actuation exhibits almost the same advantages of the traditional load control by quantity of fuel injected of Diesel engines. The use of a stoichiometric air-to-fuel mixture permits to meet emissions standards without the negative impacts on the after treatment technology that the lean stratified operation would introduce.

The electro-hydraulic variable valve actuation technology may be applied to both intake and exhaust valves to fully modify the lift profiles as needed by the engine operation. In addition to valve timing strategies as early intake valve closure or late intake valve opening, valve lift strategies are also possible with variable valve actuation. Valve lift strategies may be used to control the air quantity and the swirl and tumble charge motions in the cylinder. The variable valve actuation technology offers the potential to improve other critical areas of spark ignition engines in addition to the load control, including better charging efficiency over the 
range of engine speeds and loads, improved dynamic response, better combustion evolution, improved operation during catalyst lightoff time.

\section{PROPERTIES OF ETHANOL AND GASOLINE FUELS}

Ethanol has many advantages and disadvantages when compared to gasoline as a fuel [5-11]. Gasoline blends differ, and properties of gasoline vary with type. Nevertheless, it is possible to define reference values for gasoline as well as of ethanol to compare. When reference is made to gasoline, ethanol has a smaller Lower Heating Value (LHV), about $26.8 \mathrm{MJ} / \mathrm{Kg}$ vs. 43.2 MJ/Kg. However, the stoichiometric air/fuel ratio for ethanol is also smaller than the one for gasoline, 9.0078 vs. 14.6, or the fuel-to-air ratio is larger, 0.111 vs. 0.068 , and therefore, the amount of energy per $\mathrm{kg}$ of stoichiometric mixture is similar for ethanol and gasoline, respectively 2.68 $\mathrm{MJ} / \mathrm{Kg}$ vs. $2.77 \mathrm{MJ} / \mathrm{Kg}$.

Ethanol has a much larger Research Octane Number (RON), roughly 129 vs. 95. This permits higher compression ratios, higher boost in turbocharged engines, and better knocks limited spark advances. These two values are those generally accepted [35], even if different values may be also suggested [34] being ethanol and gasoline commercial products of variable properties.

Ethanol also has a larger heat of vaporization of $841 \mathrm{~kJ} / \mathrm{kg}$ vs.360 kJ/kg. The amount of energy available per $\mathrm{kg}$ of stoichiometric mixture to cool the charge is $84.1 \mathrm{~kJ} / \mathrm{kg}$ vs. $23 \mathrm{~kJ} / \mathrm{kg}$. This allows higher densities in the intake that may increase volumetric efficiency especially in naturally aspirated engines with PFI engines, or better cooling of the in-cylinder charge in both naturally aspirated and turbo charged DI engines. This latter feature further reduces the knock sensitivity.

Densities of gasoline and ethanol are similar, respectively $750 \mathrm{~kg} / \mathrm{m} 3 \mathrm{vs} .786 \mathrm{~kg} / \mathrm{m} 3$. However, fuel injection systems must handle larger quantities of fuel because of the lower energy content. Therefore, DI fuel injectors developed for gasoline applications should probably be revised for higher flow areas or increased injection pressures to efficiently operate with ethanol. Or alternatively, ethanol engines may have smaller unit displacements than gasoline engines and use same fuel injectors.

The flame speed of stoichiometric air mixtures with ethanol and methanol at 1 bar, $300 \mathrm{~K}$ is comparable to that of n-heptane, which is in small amounts present gasoline [8 and 12]. The flame speed of iso-octane, which is in high concentration in gasoline, is substantially smaller than the flame speed of either alcohol or n-heptane [12]. C2H5OH has a laminar flame speed of $41 \mathrm{~cm} / \mathrm{s}$, while $\mathrm{CH} 3 \mathrm{OH}$ has a laminar flame speed of $50 \mathrm{~cm} / \mathrm{s}$. C8H18 has a much smaller laminar flame speed of about $33 \mathrm{~cm} / \mathrm{s}$, while C7H16 has a laminar flame speed of about $39 \mathrm{~cm} / \mathrm{s}$ very close to the one of $\mathrm{C} 2 \mathrm{H} 5 \mathrm{OH}$. The temperature and pressure conditions for these flame speeds are different from those around spark timing in the engine, which are typically larger than 10 bar and more than $700 \mathrm{~K}$ during full load operation with maximum brake torque spark timing.

If direct fuel injection and turbo charging are two of the most effective directions in improving the efficiency of gasoline engines, there is no doubt pure ethanol engines should follow these trends. The evaporative cooling from direct ethanol injection, coupled with the high octane rating of ethanol, has been already proved to be highly effective in inhibiting knock [7]. Direct injection and turbo charging may therefore optimize pure ethanol-fuelled engines to a level of performance that exceeds gasoline engine efficiency taking full advantage of ethanol's higher research octane number and higher heat of vaporization.

\section{PROPOSED ENGINE PARAMETERS}

First task starts from two validated WAVE [22] engine performance models, one for a $2 \mathrm{~L}$ turbo charged, direct injection Diesel engine and one for a $4 \mathrm{~L}$ naturally aspirated, port fuel injection, throttle controlled G100 engine, with computed brake efficiencies and specific fuel consumptions vs. engine speed and brake mean effective pressure within a $5 \%$ of measured values. The Diesel engine is then modified to run E100 and G100 with a reduced displacement of 1.6L, replacement of the centrally located Diesel direct injector with a centrally located gasoline direct injector and spark plug, reduced compression ratio and addition of variable valve actuation modules on the intake valves to control the load throttle less. These changes that could be extremely costly on a real engine just require a few modification of the model to obtain computed brake efficiencies and specific fuel consumptions vs. engine speed and brake mean effective pressure that are expected to be not that far from actual values.

The proposed engine has direct injection, is turbo charged and has variable valve actuation. The engine is turbo charged with a fixed geometry turbine, and it has charge cooling, waste gate and exhaust gas recirculation. The main engine parameters are presented in Table 1. Fuel is directly injected within the cylinder and the engine is running stoichiometric to lower the emission of pollutants below Euro 4 standards with a three way catalytic converter (TWC). The engine has four valves per cylinder and a pent roof combustion chamber with central location of spark plug and direct injector. Piston is modified to run ethanol with an increased compression ratio of 13:1 as well as to better deal with the different fuel spray. The fuel injector considered here is a fast, high pressure fuel injector for gasoline direct injection engines ideal for spray stratified lean combustion applications [13]. Operation with gasoline at pressures 50200 bar permits static flow rates of up to $40 \mathrm{~g} / \mathrm{s}$, minimum linear flow @ $200 \mathrm{bar} 4 \mathrm{mg} / \mathrm{pulse}$, multiple injection capability with hydraulic separation at multiple injection $\leq 0.2 \mathrm{~ms}, \mathrm{D}_{32}$ Sauter mean diameter less than $10 \mu \mathrm{m} @ 200$ bar, DV 90 less than $25 \mu \mathrm{m} @ 200$ bar and cone angles as required by application in between $80^{\circ}$ and $100^{\circ}$. 
When reference is made to gasoline, piston/wall impingement issues are larger with higher fuel rates and higher heat of vaporization of oxygenates. The higher injection pressure is supposed to limit these issues.

The central injector is not a typical design for a gasoline DI engine, where a side injector is usually preferred for packaging reasons. However, the central is the more rational location of a fuel injector, and the complication of the engine layout to accommodate a central injector and a central spark plug are more than compensated by the much better mixture preparation and combustion evolution.

The 13:1 compression ratio of ethanol is not high in light of optimal performance and constraints of peak cylinder pressures in Diesel production engines.

At maximum speed and load, the inlet temperature of turbine with stoichiometric $\lambda=1$ gasoline and ethanol will be up to respectively 275 and $195 \mathrm{~K}$ larger than in the lean burn $\lambda=1.55$ Diesel.

The temperature of the burning gases with gasoline and ethanol may be reduced operating close to full load and maximum speed reducing the boost opening the waste gate, changing the air-to-fuel ratio to richer mixture, retarding the ignition timing and opening the cooled exhaust gas recirculation valve. These actions have different effects on brake efficiency, brake mean effective pressure, sensitivity to knock and turbine inlet temperature. Use of water injection $(32,33)$ and adoption of more efficient charge or exhaust gas recirculation cooler and eventually of a turbine designed for higher temperatures may be additional measures to be generally exploited.

The injection pressure from the fast actuating, multiple event high pressure injector is increased from 200 to 300 bar with ethanol. With E100, the DI injector maximum flow rate has to increase since E100 only contains $66 \%$ of gasoline energy in volume. The problem is solved using a higher pressure GDI injector specifically developed for much larger engines (the displaced volume for a single cylinder of this engine is only 0.4 litres). Injection is always performed after Intake Valve Closure (IVC). This has the advantage of injecting into hotter gas which helps to insure complete vaporization of the ethanol and prevents or minimizes wall wetting. The engine has the option to be controlled both by throttle and by reducing the intake valve lift.

Table $1-$ E100 and G100 Engine parameters.

\begin{tabular}{|c|c|}
\hline Bore B [MM] & 80 \\
\hline Stroke $\mathrm{S}[\mathrm{mm}]$ & 80 \\
\hline Bore to Stroke ratio $\mathrm{B} / \mathrm{S}$ & 1 \\
\hline Connecting rod length [mm] & 135 \\
\hline Compression ratio CR G100 & $9: 1$ \\
\hline Compression ratio CR E100 & $13: 1$ \\
\hline Intake valve reference diameter $\mathrm{D}_{\mathrm{i}}[\mathrm{mm}]$ & 27 \\
\hline Exhaust valve reference diameter $\mathrm{D}_{\mathrm{e}}[\mathrm{mm}]$ & 24 \\
\hline Intake valve maximum lift $h_{i}[\mathrm{~mm}]$ & 8.5 \\
\hline Exhaust valve maximum lift $\mathrm{h}_{\mathrm{e}}[\mathrm{mm}]$ & 8.5 \\
\hline Intake valve opening IVO [ ${ }^{\circ}$ crank angle] & $350^{\circ}\left(10^{\circ} \mathrm{BTDC}\right)$ \\
\hline Intake valve closure IVC ${ }^{\circ}$ crank angle $]$ & $580^{\circ}\left(40^{\circ} \mathrm{ABDC}\right)$ \\
\hline Exhaust valve opening EVO [ ${ }^{\circ}$ crank angle] & $140^{\circ}\left(40^{\circ} \mathrm{BBDC}\right)$ \\
\hline Exhaust valve closure EVO $\left[{ }^{\circ}\right.$ crank angle $]$ & $370^{\circ}\left(10^{\circ} \mathrm{ATDC}\right)$ \\
\hline
\end{tabular}

The high evaporation enthalpy of ethanol requires detailed examinations regarding the cold start behaviour [14-21]. Various injection strategies should be adopted to avoid the fuel film on the piston top and ensure that the first injected mass of fuel could also be ignited [14]. The larger amounts of fuel to be injected with ethanol may also increase the oil dilution. Both these aspects are not considered in the paper. Peak cylinder pressures and turbine inlet temperatures of the following application are compatible with values used in racing applications of the 70s. Peak cylinder pressures are higher than those of today's production gasoline engines, but close to those of today's production Diesel engines. Cost related thermal and structural limitations to boost are not considered in the present paper.

Valve lift strategies may be used to control the air quantity and the swirl and tumble charge motions in the cylinder. Only valve lift variations are considered here to control the load. The variable valve actuation technology offers the potential to improve other critical areas of spark ignition engines, including better charging efficiency over the range of engine speeds and loads improved dynamic response, better combustion evolution, improved operation during catalyst light-off time. 

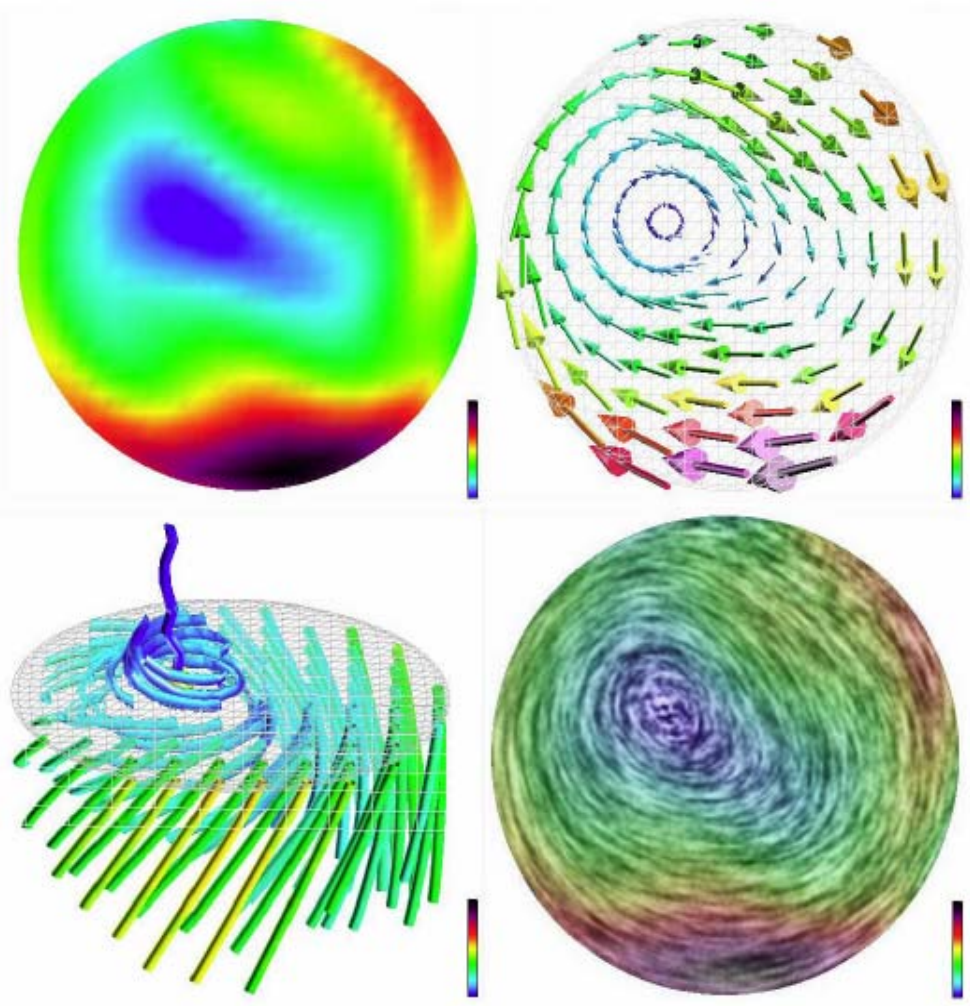

Figure 4a-Swirl motion (from [31]). (Top-left) direct visualization using colour mapping, (top-right) direct visualization using glyphs, (bottom-left) geometric flow visualization using streamlets, and (bottom-right) texture-based flow visualization.
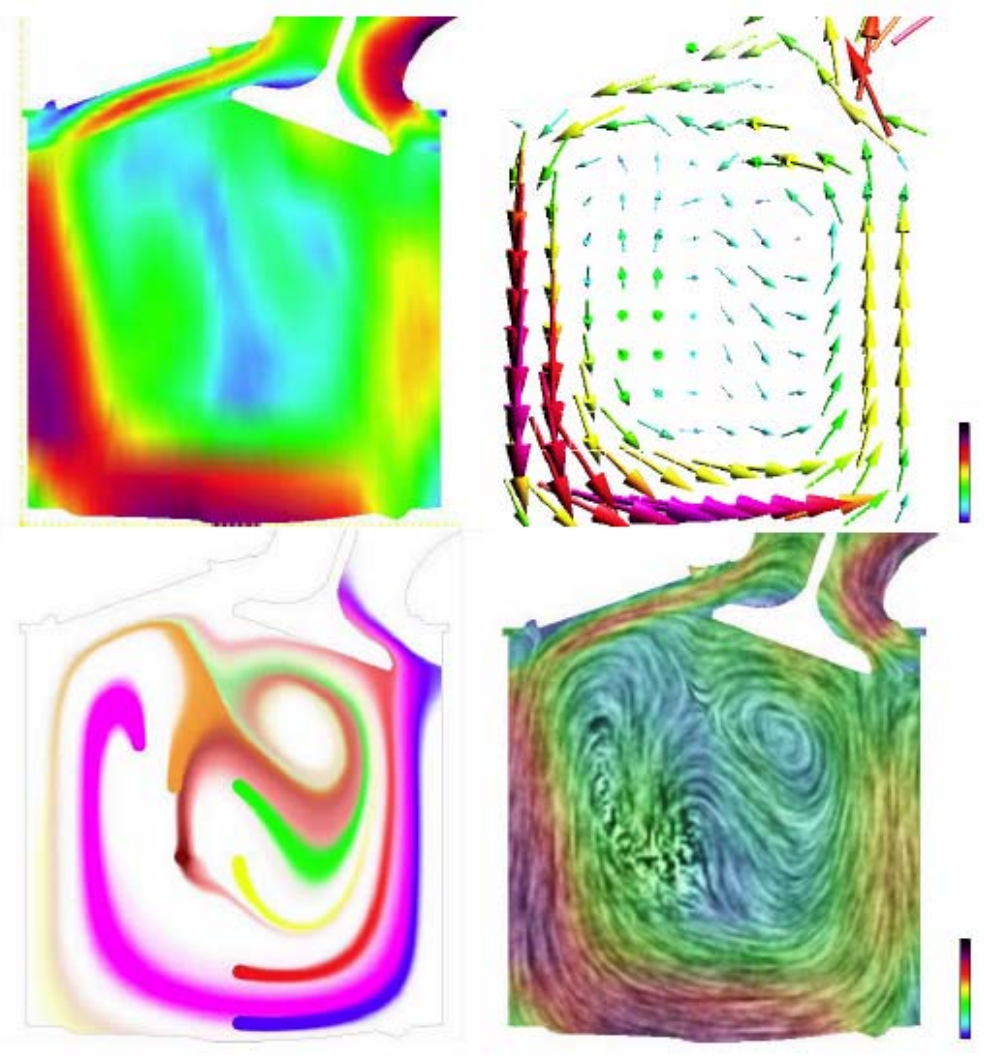

Figure $4 \mathrm{~b}$ - Tumble motion (from [31]). (top-left) direct visualization using colour mapping, (top-right) direct visualization using glyphs, (bottom-left) flow visualization using dye injection, and (bottom-right) texture-based flow visualization. 
These further benefits of the fully variable valve lift actuation are certainly worth of investigation and are not considered here just for sake of simplicity. The option to produce particulate with direct injection of liquid fuel is also not considered.

Figures $4 \mathrm{a}$ and $4 \mathrm{~b}$ present a sketch of the incoming charge motion within the cylinder. The two intake valves of a four valve gasoline engine are typically direct ports, producing tumbling motion and no swirl if the valves are operated with same valve lift profiles. In case of different valve lift profiles adopted for left and right valves, a certain amount of swirl is also produced. The two intake valves of a four valve Diesel engine may be direct, more often helical ports, or one direct and one helical, producing swirl or a combination of swirl and tumble also in case of same valve lift profiles. Again, operation with different valve lift profiles may changes the intake flow motion.

Top is the stable, circulating flow pattern in an engine designated as swirl motion, with the cylinder axis as the axis of rotation. The flow enters tangentially through the intake ports. Bottom is the transient tumble motion in an engine. The axis of motion moves as the cylinder expands and stays halfway between the top cylinder wall and the piston head at the bottom (not shown).

The swirl and tumble attitude of intake ports are usually evaluated as coefficients measured on steady test rigs where the flow is discharged downwards with an extended cylinder or side ward through a t-junction equipped with torque meters. Swirl and tumble coefficients are measured of the valve lift. In case of an independent operation of the two valves, a matrix of results could possibly replace a vector of data. Considering the difficulty to use swirl and tumble data in engine modelling, only flow coefficient data expressing flow losses through valves have been measured, and the influence of swirl and tumble is currently neglected.

\section{ENGINE RESULTS}

Results of simulations are presented for the high tech, turbo charged, direct injection engines with load control by variable valve actuation specifically developed to be fuelled with E100 or G100 fuel. Simulations have been performed using the WAVE code [22] with gasoline considered as indolene $\mathrm{C}_{7.3} \mathrm{H}_{13.9}$ and ethanol $\mathrm{C}_{2} \mathrm{H}_{6} \mathrm{O}_{1}$ as liquid fuels. Knock is simply computed with an empirical induction-time correlation model [22 and 23]. Combustion is simulated with a predictive SI turbulent combustion model [22 and 2428]. This model simulates combustion with a flame front propagating from the spark plug location through a simplified geometry. The combustion model is an extension of the work done in [24-26] as described in [27 and 28]. Mean and turbulent in-cylinder flow properties required by the previous combustion model as well as by the heat transfer model are computed as described in [20 and 29]. For what concerns the spray behaviour, despite a more complex model is available to predict the liquid fuel spray motion and evaporation within the cylinder including transport of droplets and liquid films description [22], only the effect of fuel spray evaporation on gas temperature within the cylinder is considered. The knock induction time in seconds is calculated at every time step using the following equation:

$\tau=0.01869 / A_{p} *\left(\frac{O N}{100}\right)^{3.4107} * P^{-1.7} \exp \left(\frac{3800 / A_{T}}{T}\right)$

Where $A_{p}$ is a pre-exponential multiplier, ON the fuel octane number, $P$ the cylinder pressure $\left[\mathrm{kg} / \mathrm{cm}^{2}\right], A_{T}$ the activation temperature multiplier and $\mathrm{T}$ the unburned gas temperature $[\mathrm{K}]$. This induction time continually decreases as combustion progresses and the unburned zone temperature rises. The end-gas auto-ignites (knocks) if the induction time is less than the flame arrival time. The model assumes that auto-ignition occurs when:

$\int_{t 0}^{t i} \frac{d \tau}{\tau}=1$

Where $t_{0}$ is the start of end-gas compression, $t_{i}$ the time of auto-ignition and $t$ is the induction time. If tuned to gasoline data, the simple models described above can be used to model the operation with ethanol fuel just introducing the major changes needed in fuel properties and composition with an expected satisfactory accuracy for what concerns major trends like the determination of the better than gasoline knock resistance.

Figures $5 \mathrm{a}$ and $5 \mathrm{~b}$ present the computed rate of change of entrained and burned mass vs. crank angle for G100 and E100 engines (WOT, $3000 \mathrm{Rpm}, 10^{\circ}$ spark advance). The turbulent flame speed in the mass of entrained unburned gas equation reaches values of about 1.2 times the mean piston speed about spark ignition timing, reducing to 0.93 times the mean piston speed about top dead centre. The laminar flame speed in the equations for the mass of entrained unburned gas and burned gas would reach much smaller values at top dead centre of about 0.08 times the mean piston speed. With gasoline fuels, the turbulent flame speed may be slightly larger, 1.26 vs. 1.2 about spark ignition timing, and 1.03 vs. 0.93 about top dead centre, with laminar flame speed pretty much the same about top dead centre. This is the result of the temperature drop due to the higher heat of vaporization of ethanol when compared to gasoline more than offsetting the higher laminar flame speed of ethanol for same pressure and temperature. The resulting profiles for the rate of change of entrained and burned mass fractions vs. crank angle show pretty much same profiles, with curves overlapping during combustion evolution for similar combustion durations. This is the consequence of the higher compression ratio adopted when running ethanol, as well as the temperature drop due to the higher latent heat of vaporization of ethanol, and the larger laminar flame speeds at 
same pressure and temperature of ethanol.

Figures $6 \mathrm{a}, 6 \mathrm{~b}$ and $6 \mathrm{c}$ present computational results obtained with different spark timings for knock index, Indicated Mean Effective Pressure (IMEP) and combustion duration 10-90\% mass fuel burned with E100 and gasoline at 3,000 Rpm and wide open throttle (WOT). The higher compression ratio E100 engine has only slightly larger knock indices than the gasoline engine. The knock index is more sensitive to spark advance than the combustion duration, while the indicated mean effective pressure does not change too much with spark advance. The knock results show that despite the much higher compression ratio, the ethanol engine has less sensitivity to knock than the gasoline engine. This is a result of the lower in-cylinder temperatures following vaporization of the ethanol fuel as well as the higher RON of ethanol.

The constraint of turbine inlet temperature smaller than $700 \mathrm{C}(973 \mathrm{~K})$ running higher engine speeds is less significant with ethanol than gasoline thanks to the higher heat of vaporization of ethanol and is controlled in the proposed application by carefully controlling cooled exhaust gas recirculation, spark advance, mixture enrichment and waste gate opening. Figures $7 \mathrm{a}, 7 \mathrm{~b}$ and $7 \mathrm{c}$ present results obtained with E100 for full load turbine inlet temperature, brake efficiency and mean effective pressure with stoichiometric air-to-fuel ratio and EGR and waste gate valve closed, and with a fuel rich mixture and EGR and waste gate valve open.

Figures $8 \mathrm{a}, 8 \mathrm{~b}$ and $8 \mathrm{c}$ present computational results obtained for brake power, torque and efficiency. These points have been computed with wide open throttle (WOT) and maximum brake torque or knock limited spark advance. Power and torque results show the E100 engine delivers much better performance. Improvements vary from 20 to $28 \%$ over the range of engine speed. Maximum torque and power outputs are increased $20 \%$ and $23 \%$ respectively. In terms of fuel conversion efficiency, it increases with E100 17 to $23 \%$, or 5.70 to 6.25 points over the range of engine speeds.

These results are quite interesting, in line with what was expected following [7-10], showing the direct injection, turbo charged engine specifically designed for running ethanol, basically with few hardware modifications from a gasoline engine, may have much better fuel conversion efficiencies and power densities than gasoline. Today's port fuel injected naturally aspirated flex-fuel engines still have a significant penalty in efficiency running E85 when reference is made to the base gasoline engine simply because the flexi fuel operation reduces the maximum compression ratio that could be used with ethanol, with even larger differences permitted by direct injection.

Figures 9a and 9b show the computed engine brake efficiency and mean effective pressure for the E100 engine changing the maximum intake valve lift. Controlling the load by variable valve actuation is effective in producing high efficiencies from $25 \%$ of full load.

Figure 9a shows the brake efficiency at various values of the maximum intake valve lift, i.e. full opening and 50,25 and $12.5 \%$ of full opening, as well as the brake efficiency at various engine BMEP outputs of 12.5, 7.5, 4.25 and 3.75 bar obtained with different valve lifts. Figure $9 \mathrm{~b}$ shows the BMEP produced at various values of the maximum intake valve lift. The engine output does not change too much reducing considerably the maximum valve lift. Differences start to be significant when the maximum valve lift is a $12.5 \%$ of full opening at higher speeds. It is to be pointed out that the fully variable valve lift can further improve the part load combustion because of the influence on combustion presently neglected acting on the combined tumble and swirl motions.

Figures 10a and 10b present the brake specific fuel consumption and brake efficiency maps of the Turbo charged, variable valve lift controlled 1.6L E100 engine, while Figures $11 \mathrm{a}$ and $11 \mathrm{~b}$ present the brake specific fuel consumption and brake efficiency maps of the Turbo charged, variable valve lift controlled 1.6L G100 engine. The G100 engine has lower (better) BSFC but worse efficiency because of fuel LHV differences. These results are computational results with differences vs. experiments done on a properly operating and well maintained engine dynamometer expected to be less than $10 \%$.

For what concerns the E100 engine, the top efficiency is $39.2 \%$, corresponding to a brake specific fuel consumption of $342 \mathrm{~g} / \mathrm{kWh}$. The brake specific fuel consumption for operation at 1 bar brake mean effective pressure and 1,500 rpm is $574 \mathrm{~g} / \mathrm{kWh}$ corresponding to an efficiency of $23.4 \%$. The G100 engine has a top efficiency is $33.2 \%$, corresponding to a brake specific fuel consumption of 251 $\mathrm{g} / \mathrm{kWh}$. The brake specific fuel consumption for operation at 1 bar brake mean effective pressure and $1,500 \mathrm{rpm}$ is $430 \mathrm{~g} / \mathrm{kWh}$ corresponding to an efficiency of $19.4 \%$.

Use of these small displacement, high power density engines to replace a large displacement, low power density engine (for example the naturally aspirated, throttle controlled gasoline engine of brake specific fuel consumption and efficiency of maps in Figures 2 a and 2b) may considerably improve fuel economy not only for the better top and part load efficiencies, but also for the much better operation following downsizing.

To produce the same instantaneous power of a $4 \mathrm{~L}$ gasoline, the downsized 1.6L E100 and G100 engines must run not 1, but 4/1.6=2.5 bar brake mean effective pressure.

The brake specific fuel consumption for operation at 2.5 bar brake mean effective pressure and 1,500 rpm of the E100 engine is 520 $\mathrm{g} / \mathrm{kWh}$ corresponding to an efficiency of $25.7 \%$, i.e. more than double the efficiency of the naturally aspirated $4 \mathrm{~L}$ gasoline engine. The G100 engine has a brake specific fuel consumption of $370 \mathrm{~g} / \mathrm{kWh}$ corresponding to an efficiency of $22.5 \%$. 


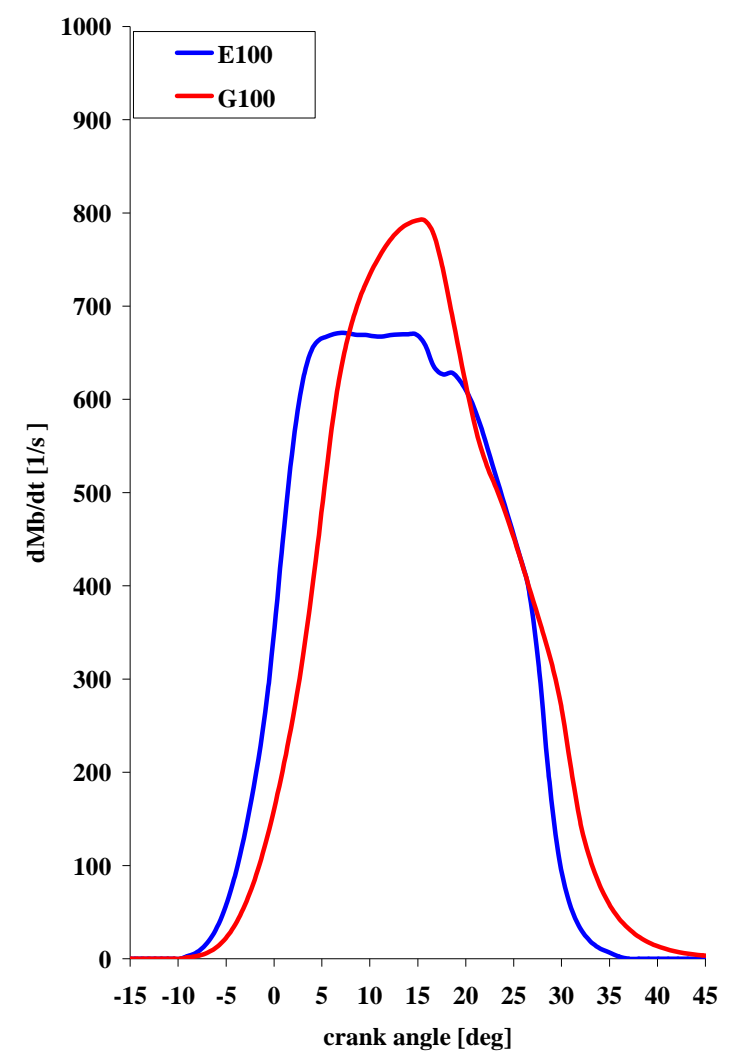

Figure 5a - Rate of change of entrained mass vs. crank angle (WOT, $3000 \mathrm{Rpm}, 10^{\circ} \mathrm{spark} \mathrm{adv}$.).

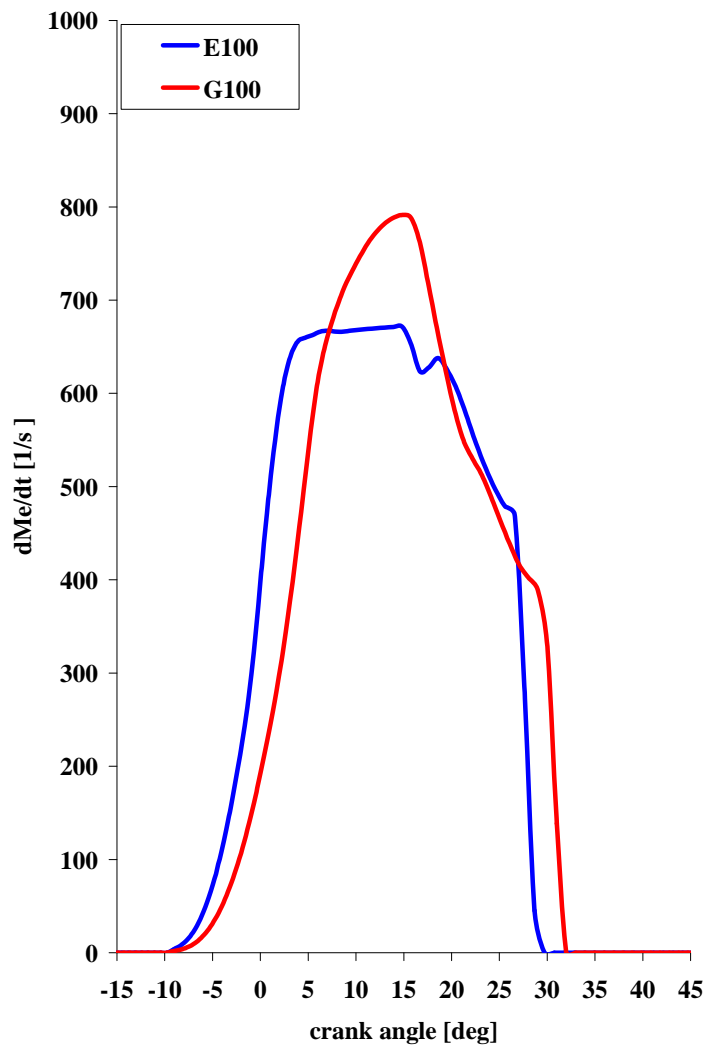

Figure $5 \mathrm{~b}$ - Rate of change of burned mass vs. crank angle (WOT, $3000 \mathrm{Rpm}, 10^{\circ}$ spark adv.). 


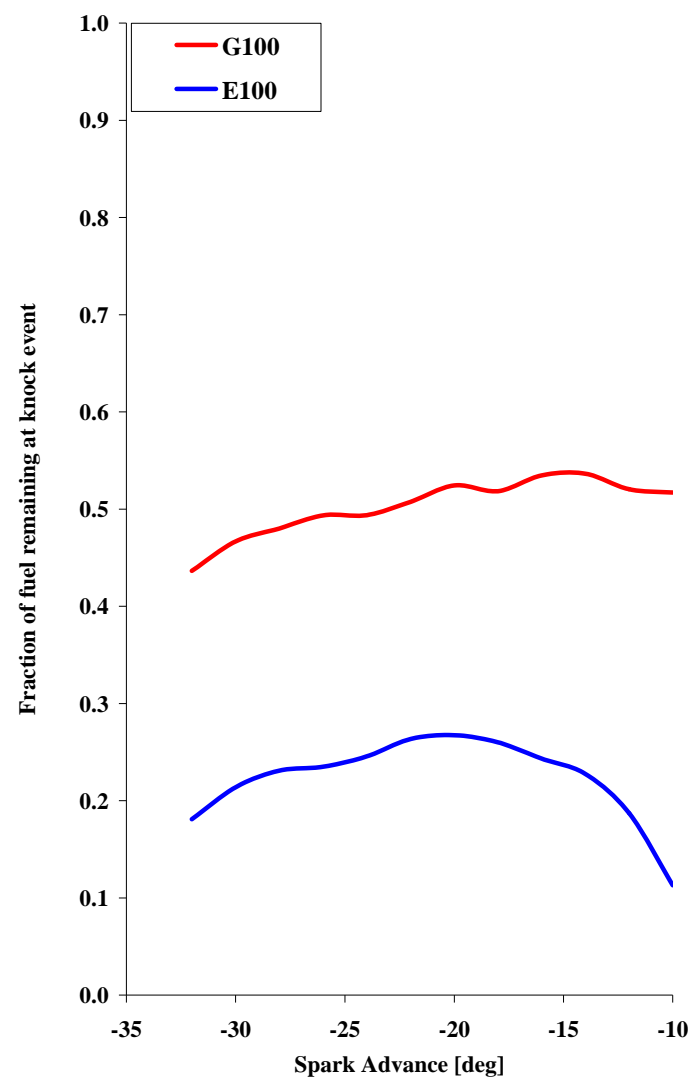

Figure 6a - Knock intensity vs. spark timing (WOT, 3000 Rpm).

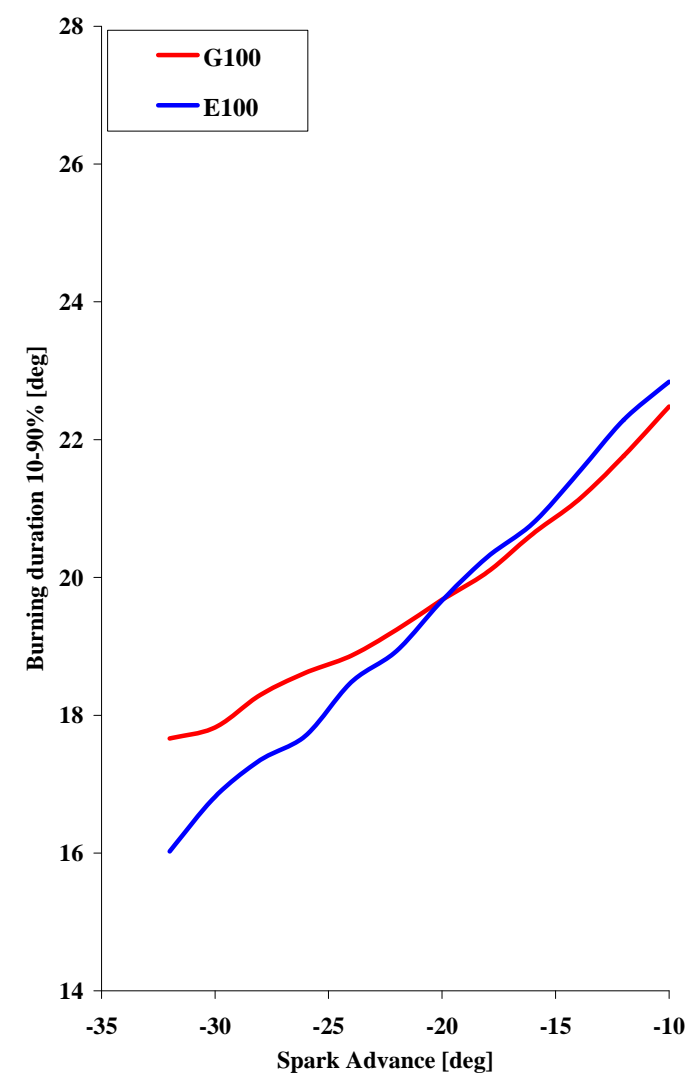

Figure $6 \mathrm{~b}$ - Burning duration $10-90 \%$ vs. spark timing (WOT, 3000 Rpm). 


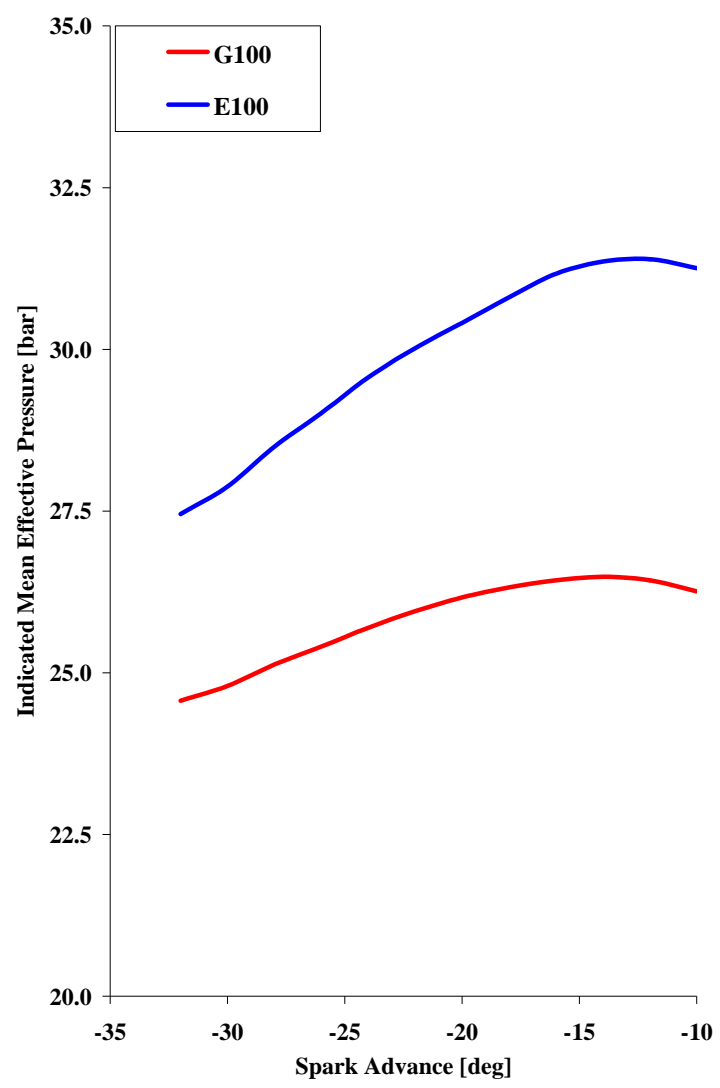

Figure 6c - IMEP vs. spark timing (WOT, 3000 Rpm).

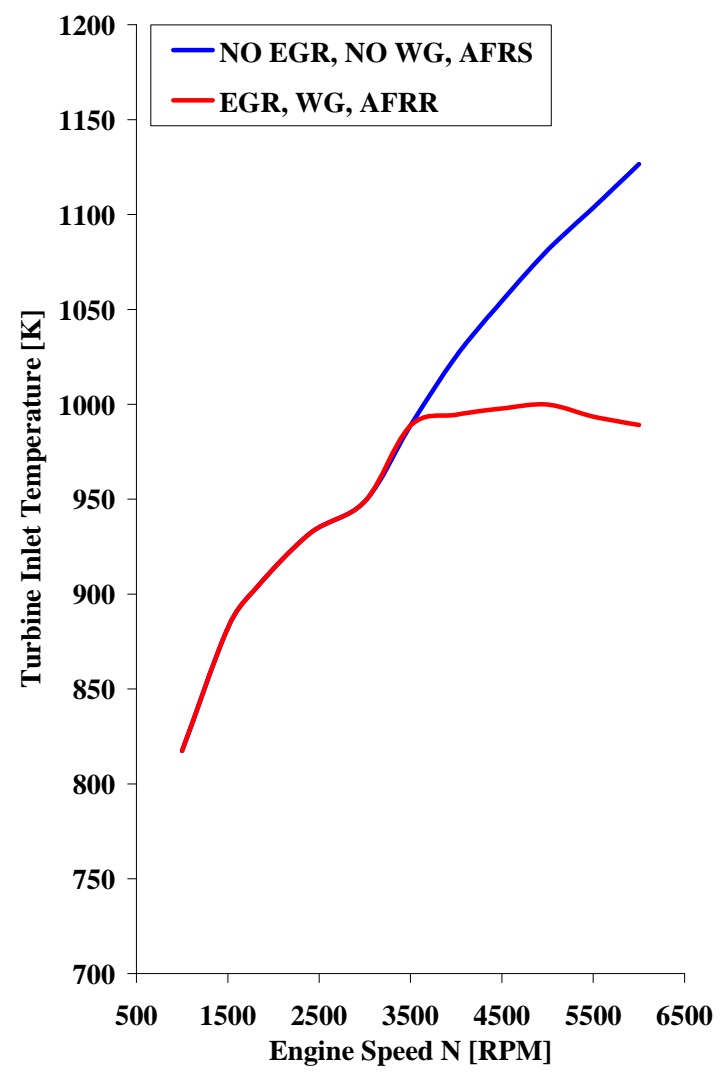

Figure 7a-Full load turbine inlet temperature with E100. 


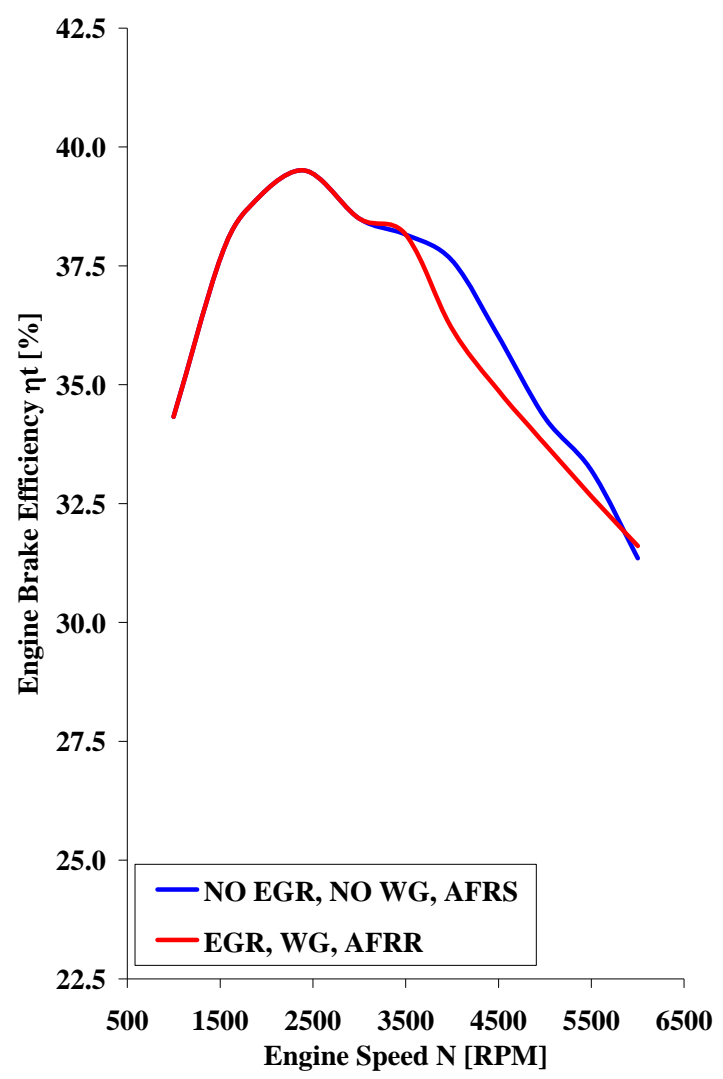

Figure $7 b$ - Full load brake efficiency with E100.

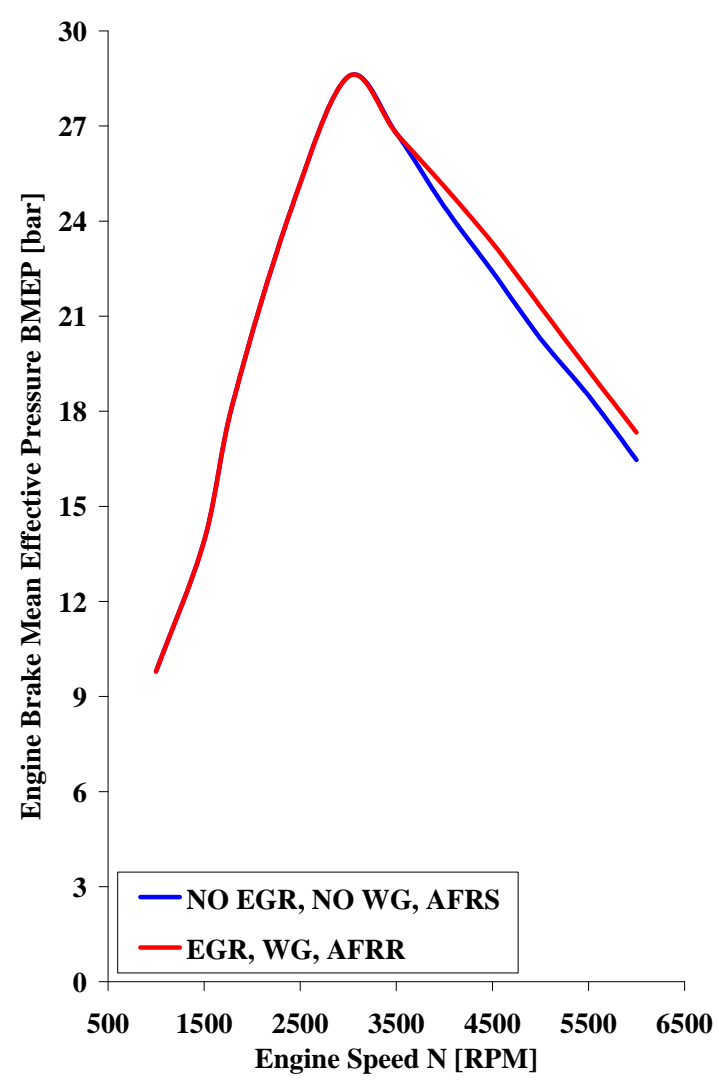

Figure 7c-Full load brake mean effective pressure with E100. 


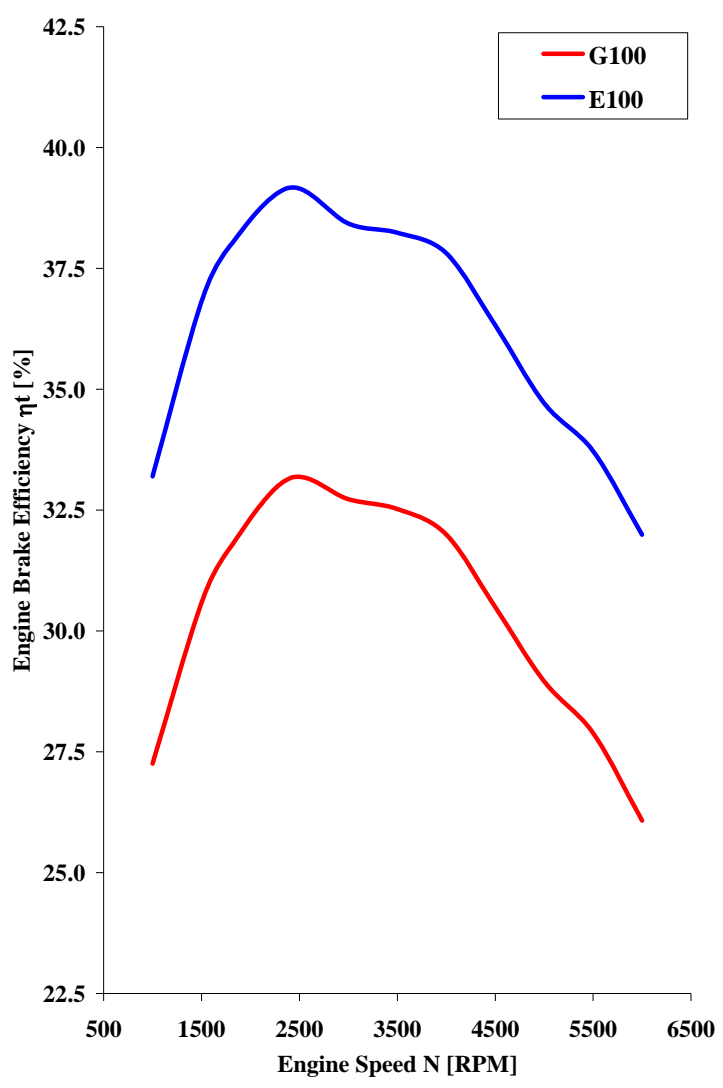

Figure 8a - Engine brake efficiency (MBT or knock limited spark timing).

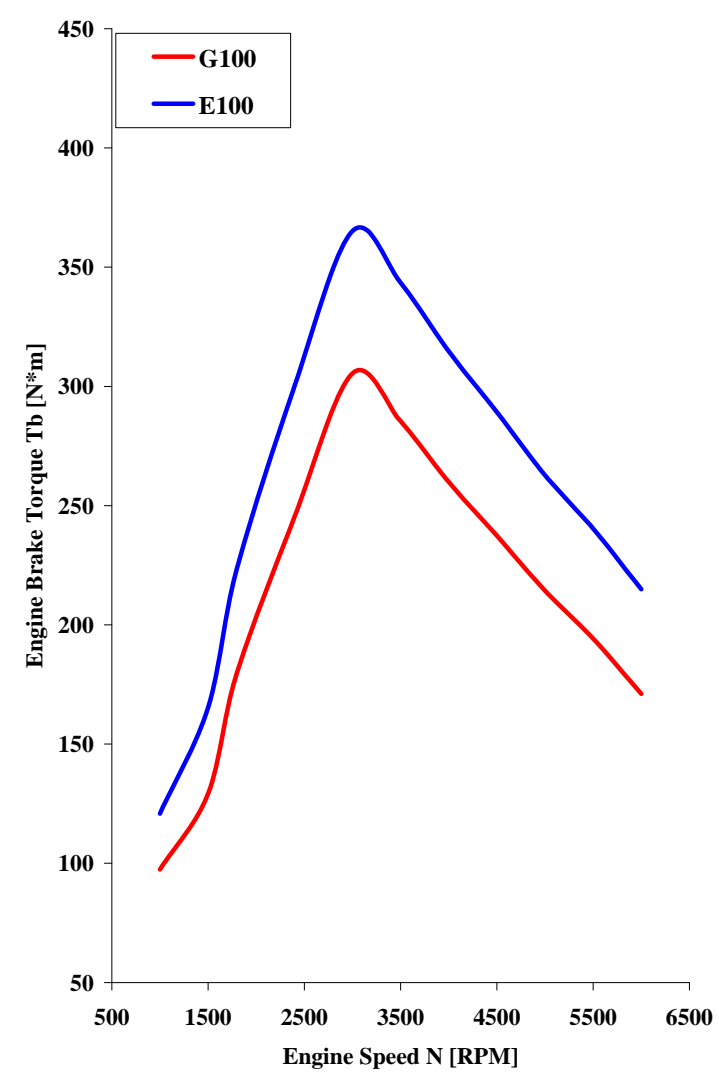

Figure $8 \mathrm{~b}$ - Engine brake torque (MBT or knock limited spark timing). 


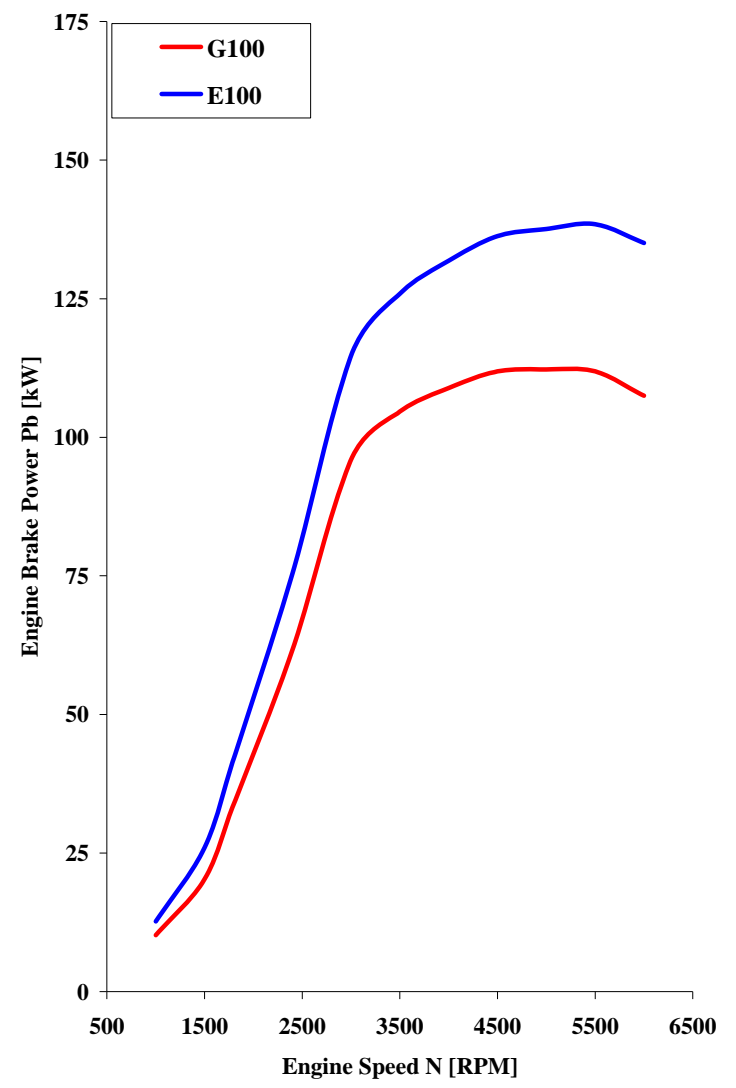

Figure 8c - Engine brake power (MBT or knock limited spark timing).

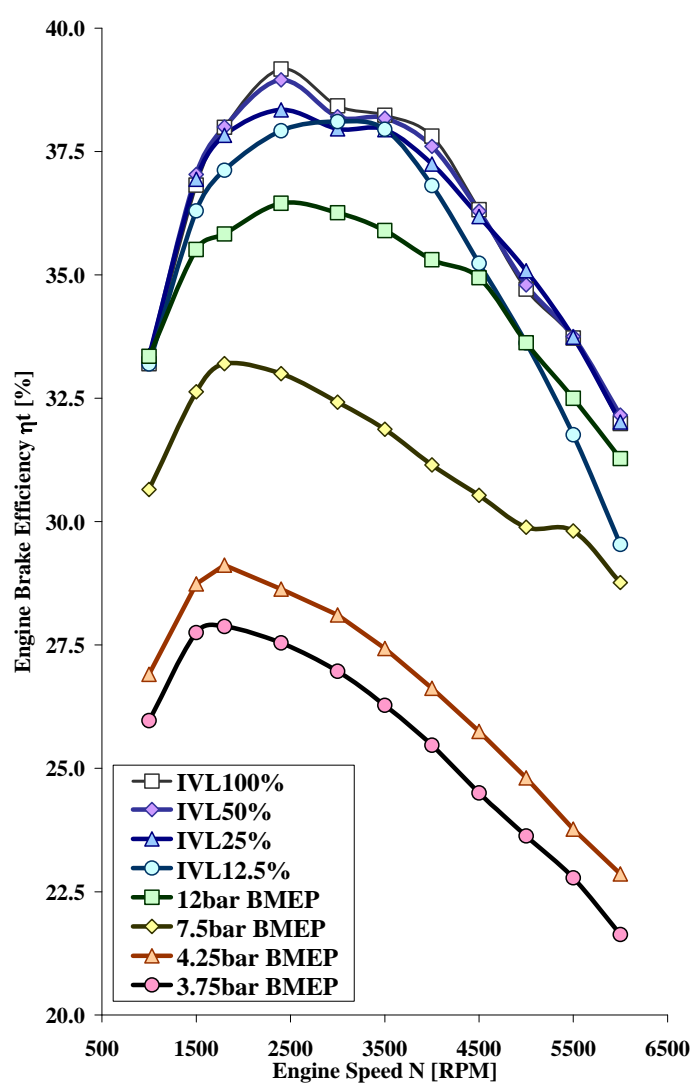

Figure 9a - Engine brake efficiency for the E100 engine at various intake valve lift (MBT or knock limited spark timing). 


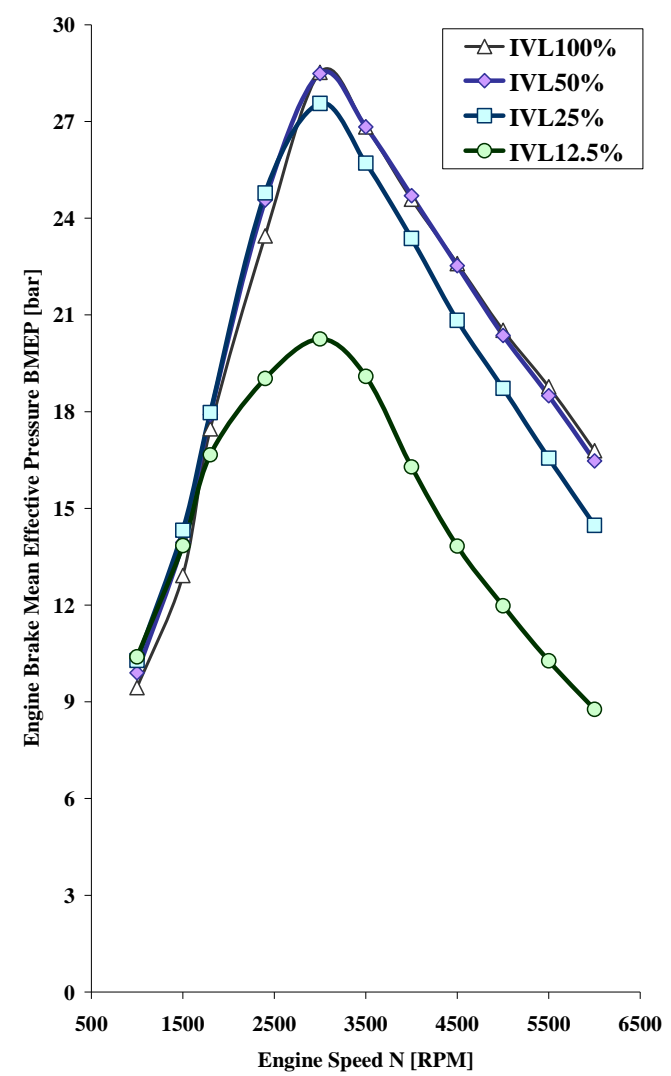

Figure 9b - Engine BMEP for the E100 engine with various intake valve lift (MBT or knock limited spark timing).

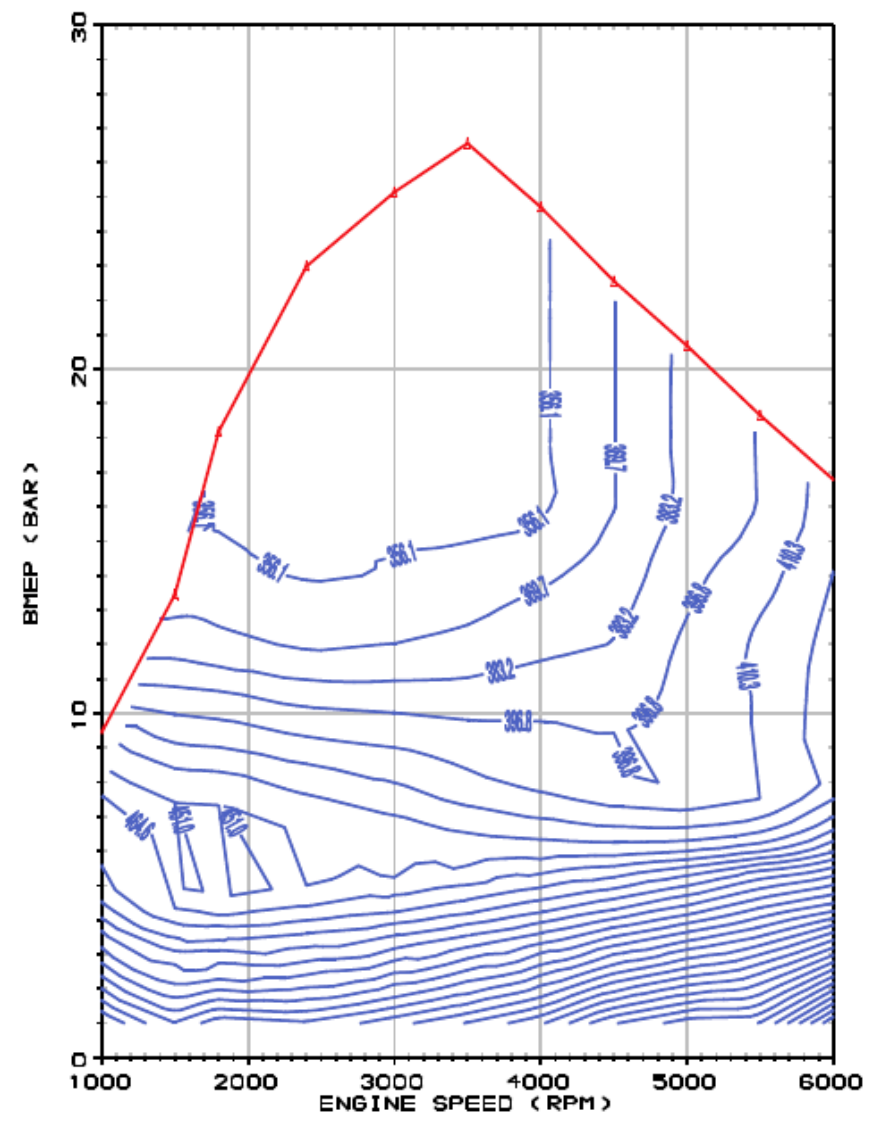

Figure $10 \mathrm{a}-\mathrm{BSFC}(\mathrm{g} / \mathrm{kWh})$ of the $1.6 \mathrm{~L}$ E100 engine. 


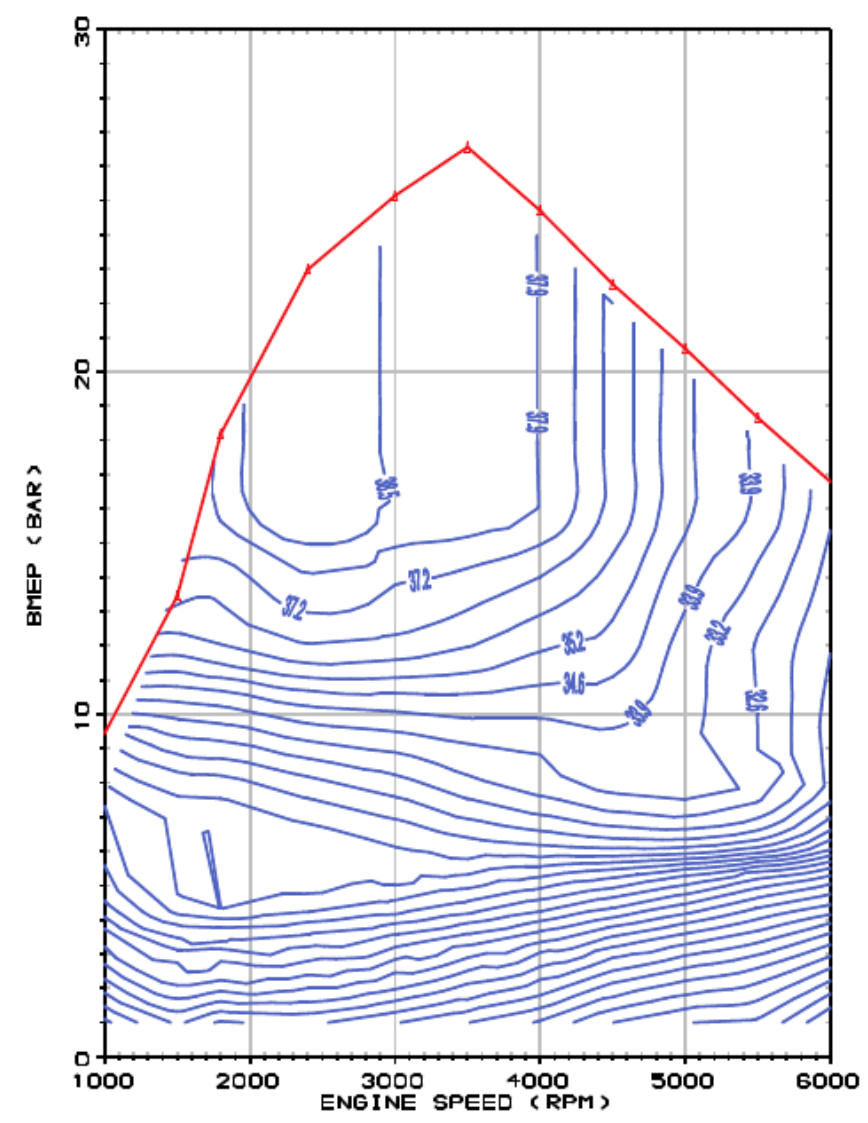

Figure 10b - Brake efficiency of the 1.6L E100 engine.

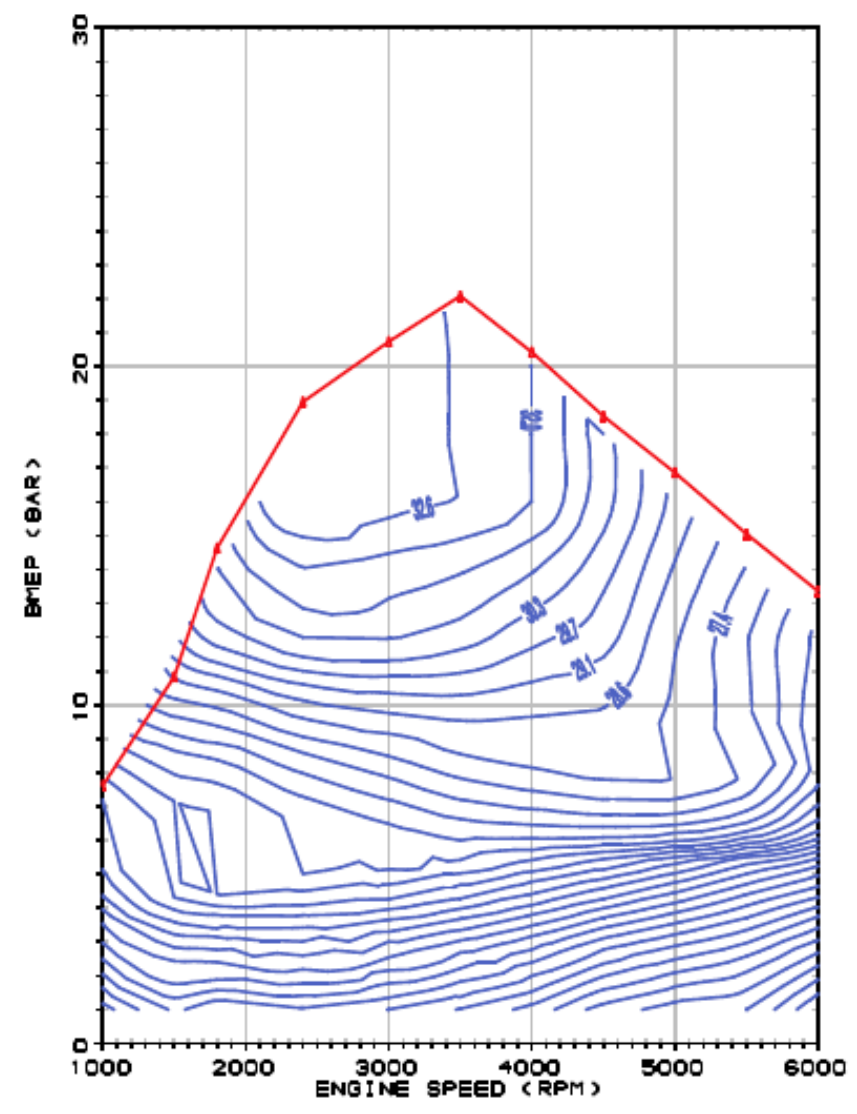

Figure $11 \mathrm{a}-\mathrm{BSFC}(\mathrm{g} / \mathrm{kWh})$ of the $1.6 \mathrm{~L}$ G100 engine. 


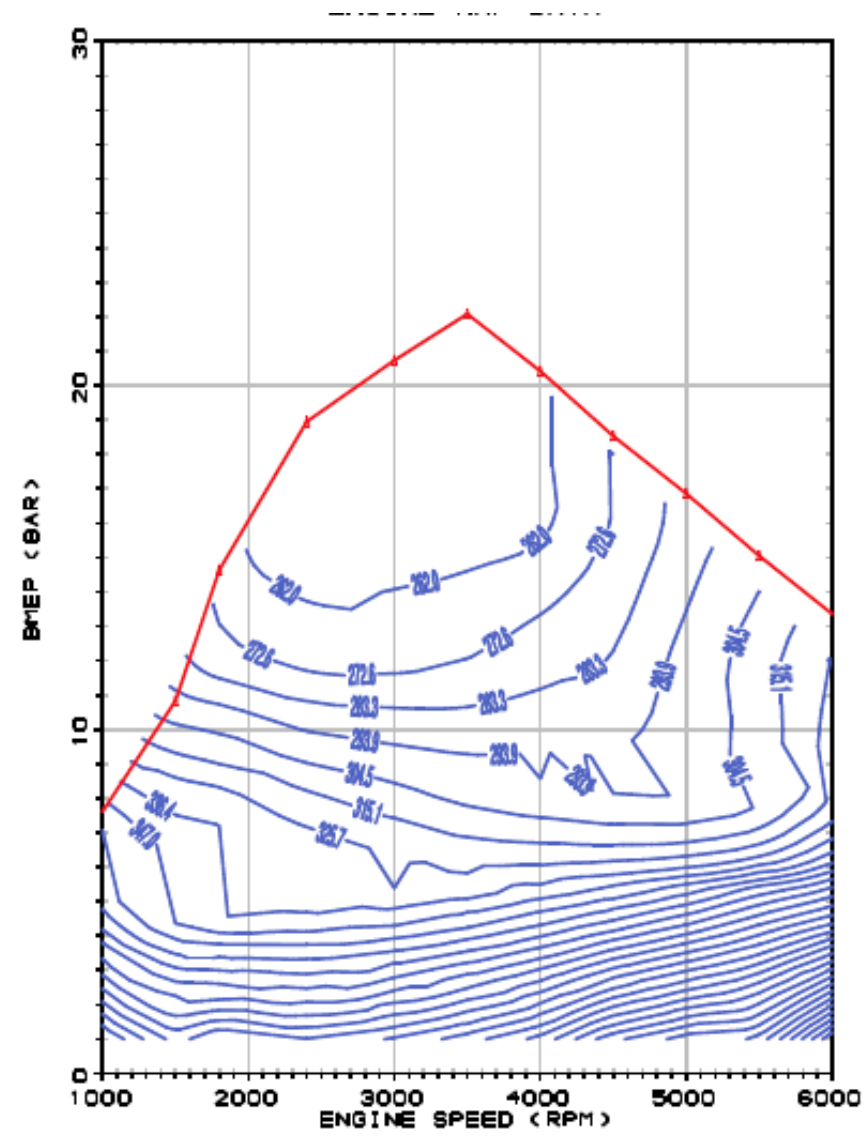

Figure $11 \mathrm{~b}$ - Brake efficiency of the $1.6 \mathrm{~L}$ G100 engine.

A dedicated E100 engine using direct injection, turbo charging and variable valve actuation may therefore have full load and part load efficiencies (1) slightly better than a dedicated gasoline engine have same features but a reduced compression ratio, and (2) much better than those of today's naturally aspirated gasoline engines.

The dedicated E100 engine with direct injection, turbo charging and variable valve actuation will have performances worse than those of lean burn diesel engines, mostly because of the lean operation of the Diesel and the higher compression ratio. However, the E100 engine has the advantage vs. Diesel of the much more developed and reliable after treatment system to meet future emission standards for the stoichiometric operation and the higher power density permitted by the option to run higher engine speeds.

When reference is made to the Diesel engine of brake specific fuel consumption and efficiency of maps in Figures $3 \mathrm{a}$ and $3 \mathrm{~b}$, the top brake efficiencies and the part load efficiencies are lower. However, the spark ignition engine may permit a better downsizing thanks to the much larger power density than a Diesel. While the Diesel combustion is limited to speeds well below 5,000 rpm, the spark ignited E100 engine has indeed no problem if not mechanical constraints to run higher speeds.

When compared to standard large naturally aspirated gasoline engines, significant benefits in terms of vehicle fuel economy derive from the high top and part load efficiencies and the high power density of the E100 engine resulting from the high boost pressure and compression ratio, the large speed of rotation and the throttle-less load control. The vehicle fuel economy is therefore expected to approach the one of Diesel.

A reduction in displacement implies the engine will be used over a cycle with a proportional increase in BMEP, with the embedded benefits in terms of efficiency running higher BMEP. The most part of the fuel consumption map is covered by low (for ethanol) BSFC values. BSFC increases reducing the load because of the constant air-to-fuel ratio and the increasing relative magnitude of friction vs. indicated mean effective pressure. At idle, BSFC are theoretically infinite (a certain amount of fuel is consumed to produce and indicated mean effective pressure equal to the friction mean effective pressure, with no brake mean effective pressure output). Finite conventional values are extrapolated from neighbouring points for idle operation.

It is to be pointed out that the constraint of turbine inlet temperature smaller than $700 \mathrm{C}(973 \mathrm{~K})$ running higher engine speeds is less demanding with ethanol than gasoline thanks to the higher heat of vaporization of ethanol. This condition is ensured in the proposed application by carefully controlling cooled exhaust gas recirculation, spark advance, mixture enrichment and waste gate opening. Other changes including different charge and EGR coolers, water injection [32, 33] and high temperature turbines may be considered 
in other circumstances.

\section{VEHICLE RESULTS}

Second task starts from a validated Lotus [30] vehicle simulation model for a Full size passenger car equipped with the 4L naturally aspirated, port fuel injection, throttle controlled G100 engine, with computed fuel economies over the new European driving cycle within a $5 \%$ of measured values. The vehicle model is then modified to use the brake specific fuel consumption maps of the $1.6 \mathrm{~L}$ high power density, turbo charged, direct injection, variable valve actuation load controlled engine optimized for E100. These changes that could be extremely costly on a real vehicle just require a few modification of the model to obtain fuel economies that are expected to be not that far from actual values.

Fuel economy is measured over test cycles. The ECE+EUDC cycle is a test cycle performed on a chassis dynamometer used for emission certification of light duty vehicles in Europe [EEC Directive 90/C81/01]. The entire cycle includes four ECE segments, repeated without interruption, followed by one EUDC segment. Before the test, the vehicle is allowed to soak for at least 6 hours at a test temperature of $20-30^{\circ} \mathrm{C}$. It is then started and the emission sampling begins at the same time. This cold-start procedure is also referred to as the New European Driving Cycle (NEDC). The ECE cycle is an urban driving cycle, also known as UDC. It was devised to represent city driving conditions, e.g. in Paris or Rome. It is characterized by low vehicle speed, low engine load, and low exhaust gas temperature. The EUDC (Extra Urban Driving Cycle) segment has been added after the fourth ECE cycle to account for more aggressive, high speed driving modes. The maximum speed of the EUDC cycle is $120 \mathrm{~km} / \mathrm{h}$. Table 2 summarizes the parameters for both the ECE and EUDC cycles. New European Driving Cycle (NEDC) simulations have then been performed for a large Full size passenger car with the Lotus Vehicle Simulation software [30]. The main vehicle parameters are summarized in Table 3.

Table 2 - Main characteristics of ECE and EUDC cycles.

\begin{tabular}{||c|c|c||}
\hline Characteristics & ECE 15 & EUDC \\
\hline Distance [km] & $4 \times 1.013=4.052$ & 6.955 \\
\hline Duration [s] & $4 \times 195=780$ & 400 \\
\hline Average Speed [km/h] & 18.7 (with idling) & 62.6 \\
\hline Maximum Speed [km/h] & 50 & 120 \\
\hline
\end{tabular}

Table 3 - Vehicle parameters.

\begin{tabular}{||c|c|}
\hline \hline Mass $\mathrm{m}[\mathrm{kg}]$ & 1810 \\
\hline Frontal area $\mathrm{A}\left[\mathrm{m}^{2}\right]$ & 2.250 \\
\hline Drag coefficient $\mathrm{C}_{\mathrm{D}}$ & 0.298 \\
\hline Rolling tire radius R $[\mathrm{m}]$ & 0.3160 \\
\hline Transmission & 5 -speed automatic \\
\hline Transmission ratios & $3.22 / 2.29 / 1.55 / 1.00 / 0.75$ \\
\hline Final drive ratio & 2.730 \\
\hline
\end{tabular}

The 4L, in-line six, throttle body controlled, naturally aspirated gasoline engine with max. power $190 \mathrm{~kW}$ and maximum torque 380 $\mathrm{N} \cdot \mathrm{m}$ is replaced first by the high tech, 1.6 litre, in-line four, valve lift controlled, turbo charged G100 engine described above, having $115 \mathrm{~kW}$ maximum power and $305 \mathrm{~N} \cdot \mathrm{m}$ maximum torque, then by the high tech, 1.6 litre, in-line four, valve lift controlled, turbo charged E100 engine described above, having $140 \mathrm{~kW}$ maximum power and $365 \mathrm{~N} \cdot \mathrm{m}$ maximum torque.

The brake specific fuel consumption vs. brake mean effective pressure and engine speed maps are those presented in Figures 2 , 10 and 11. Vehicle, tyre, driveline and gearbox data are kept constant for the two engines, as well as the shift strategy, that is the one defined for optimum use of the $4 \mathrm{~L}$ engine.

Figures 12a and 12b present the operating BMEP points vs. engine speed for the 4L G100 and the 1.6L G100 and E100 engines. The displacement effect shifts up by a factor of 4/1.6 the operating BMEP of the small engines. The naturally aspirated gasoline engine works the most of the time at 1.5 bar BMEP and $1500 \mathrm{rpm}$, while the turbocharged E100 and G100 engines work the most of the time at 3.75 bar BMEP and $1500 \mathrm{rpm}$. Table 4 presents the fuel economy results obtained with the $4 \mathrm{~L}$ gasoline, the $1.6 \mathrm{~L}$ gasoline and the $1.6 \mathrm{~L}$ ethanol engines.

The 4L gasoline engine uses $936 \mathrm{~g}$ of a fuel having LHV=43.2 MJ/Kg and density $750 \mathrm{~kg} / \mathrm{m}^{3}$ to cover over the $1180 \mathrm{~s}$ total cycle time the $11.028 \mathrm{~km}$ distance travelled of the NEDC, for a fuel consumption of 11.3 litres per $100 \mathrm{~km}$. The computational result for the baseline configuration with the $4 \mathrm{~L}$ gasoline engine agrees very well with the experiments done on a properly operating and well maintained chassis dynamometer. 


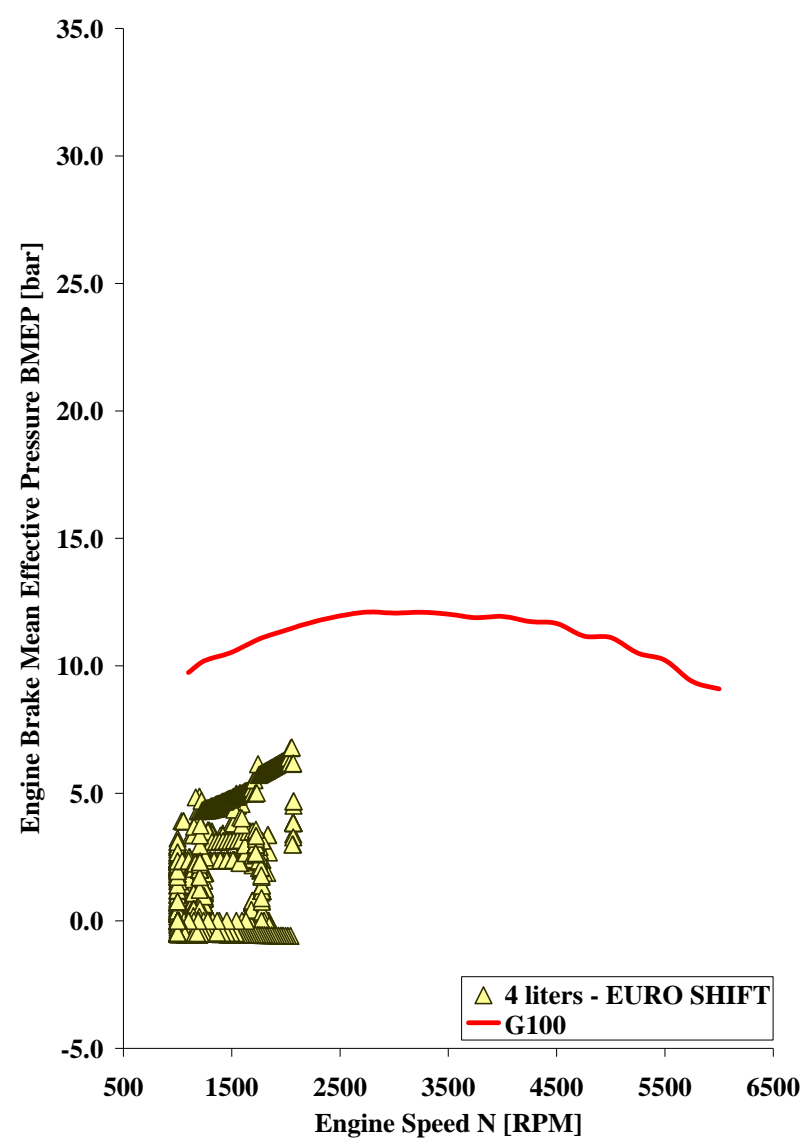

Figure 12a - Engine BMEP during the NEDC for the naturally aspirated 4L engine.

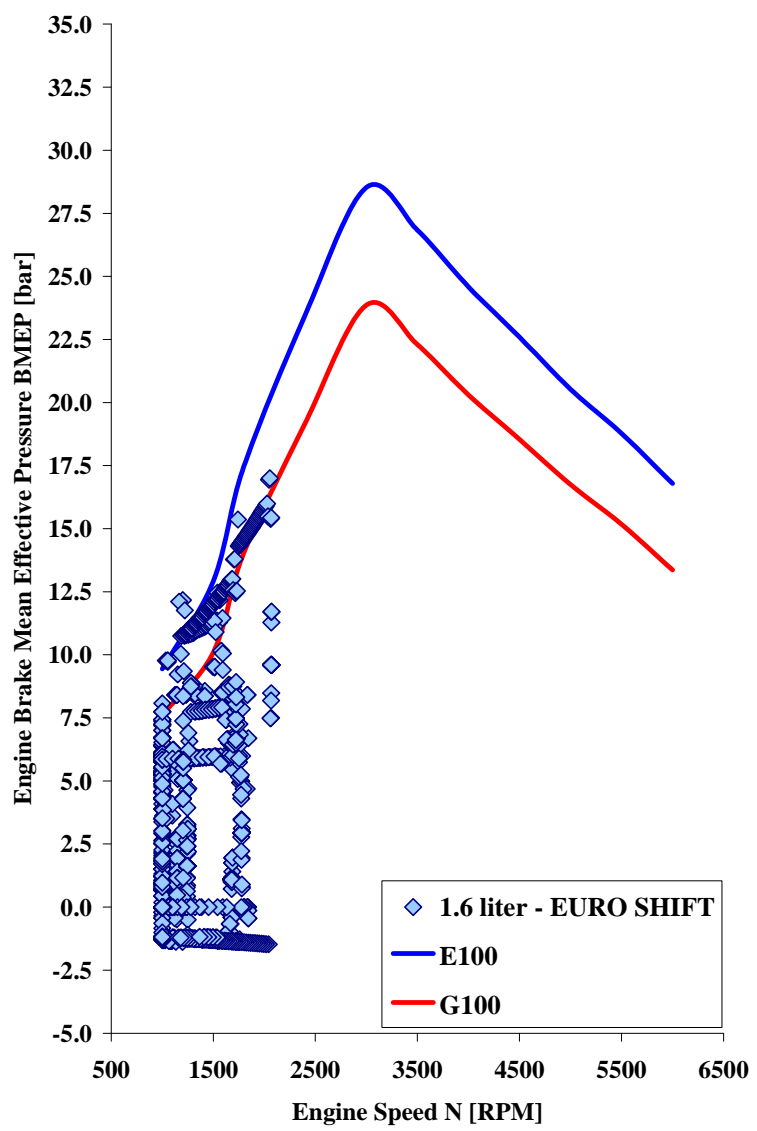

Figure 12b - Engine BMEP during the NEDC for the turbocharged 1.6L engines. 
Table 4 - Fuel consumption results for the Full size passenger car equipped with the 4L and 1.6L engines.

\begin{tabular}{|c|c|c|c|}
\hline Engine & 4L NA G100 & 1.6 TDI G100 & 1.6 TDI E100 \\
\hline Fuel specific weight & 0.750 & 0.750 & 0.786 \\
\hline Fuel lower calorific value $[\mathrm{KJ} / \mathrm{Kg}]$ & 43,200 & 43,200 & 26,800 \\
\hline Litres per $100 \mathrm{~km}$ & 11.3 & 8.4 & 10.3 \\
\hline Km per Litre & 8.8 & 11.9 & 9.7 \\
\hline Grams per Test & 936 & 684 & 896 \\
\hline Grams per KM & 85 & 63 & 81 \\
\hline Mean Consumption $[\mathrm{g} / \mathrm{h}]$ & 2858 & 2086 & 2732 \\
\hline Mean Spec. Consumption [g/kwh] & 512 & 386 & 492 \\
\hline Overall Cycle Efficiency \% & 16.3 & 21.6 & 27.3 \\
\hline
\end{tabular}

Vehicle driving cycle simulations generally provide reasonably accurate results interpolating the steady state specific fuel consumption maps, with some tuning usually requested only to model the cold start behaviour accounting for about a $10 \%$ penalty in fuel economy. In this particular case, differences between experiments and simulations are within 5\% accuracy.

Even if the transmission is not optimized for the new engine, and no weight reduction is considered replacing the large naturally aspirated gasoline engine with the smaller turbo charged engines, the 1.6L E100 engine only uses $896 \mathrm{~g}$ of a fuel having LHV=26.8 $\mathrm{MJ} / \mathrm{Kg}$ and density $786 \mathrm{~kg} / \mathrm{m}^{3}$, for a fuel consumption of 10.365 litres per $100 \mathrm{~km}$.

In terms of fuel energy, the small high tech E100 engine therefore uses $40 \%$ less fuel energy than one large naturally aspirated low tech gasoline engine, permitting an even better driving range with one full fuel tank despite of the much lower energy content of E100.

This is due to the higher BMEP permitted by downsizing (2.5 times larger operating BMEP following the displacement ratio), the larger top brake efficiency permitted by high compression ratio, the cooling due to direct injection cooling, the high boost from turbo charging partially recovering the exhaust waste heat, the spark advances closer to maximum brake torque, and the larger part load efficiencies due to the factors above plus the load control throttle-less by changing the lift of the intake valves.

The 1.6L E100 and G100 engines can not replace the G100 4L engine providing same acceleration and top speed. However, normal road driving never permits to experience these speeds and accelerations, and the downsized engines still permit vehicle performances well in excess of speed limits, with a still significant allowance for power and torque to deal with towing and hill climbing.

The proposed 1.6L is the correct displacement for a high power density, turbocharged, directly injected engine with ethanol when motoring full size passenger cars, still providing large power margins for fun driving and climbing of hills or towing. Maximum speed is indeed $215 \mathrm{~km} / \mathrm{h}$ with the $1.6 \mathrm{~L}$ ethanol engine, vs. the $230 \mathrm{~km} / \mathrm{h}$ of the $4 \mathrm{~L}$ gasoline, with gradability, grade velocity and towing being also modestly affected.

\section{CONCLUSIONS}

The paper has provided two computational assessments. First, a small high power density, turbo charged, direct injection, variable valve actuation load controlled engine optimized for E100 (pure ethanol) may run higher compression ratios and boost pressures and use better spark advances than same engine optimized for G100 (pure gasoline) thanks to the larger octane number and heat of vaporization of E100, providing better fuel conversion efficiencies.

Second, small high power density, turbo charged, direct injection, variable valve actuation load controlled engines optimized for E100 or G100 may operate during driving cycles much more efficiently that large small power density, naturally aspirated, port fuel injection, throttle controlled E100 or G100 engine thanks to the much better part load efficiency for same instantaneous brake torque and speed of the engine, providing much better fuel energy usage.

The paper provides a first description of how a state-of-the-art pure ethanol engine designed using fast actuating high pressure fuel direct injection, high boost turbo charging and fully variable valve actuation. Extensively validated engine and vehicle simulations packages have been used to produce engine brake specific fuel consumption maps and vehicle fuel economy over driving cycles expected to be within $5 \%$ accuracy vs. experiments.

Direct fuel injection and turbo charging are the two key features pure ethanol engines should have to take full advantage of ethanol's higher research octane number and heat of vaporization. Direct injection permits to cool down the charge and improve the knock tendency. Turbo charging recover part of the exhaust energy. Direct injection and turbo charging permits higher compression ratio, higher boost pressure and spark advances less limited by knock and more close to maximum brake torque values for improved fuel conversion efficiency and increased power density. 
The increased fuel conversion efficiency and the increased power density considerably improve vehicle fuel economy over driving cycles. The increased fuel conversion efficiency reduces the amount of fuel requested for a certain BMEP, the increased power density permits through downsizing operation at higher BMEP having better efficiencies.

The proposed direct injection, turbo charged pure ethanol engine basically differs from a gasoline engine in the direct injector selection, the direct injector operating pressure, the piston shape and the compression ratio. With reference to gasoline, the E100 engine has an increased injection pressure (300 bar vs. 200 bar) and an increased compression ratio (13:1 vs. 9:1). The ethanol engine also has a different piston shape to better deal with the ethanol spray.

Improvements in power and torque vary from 20 to $28 \%$ over the range of engine speed, while the fuel conversion efficiency increases 17 to $23 \%$, or 5.70 to 6.25 points, up to values about $40 \%$ in the ethanol engine vs. the parent gasoline engine. Despite of the higher compression ratio, the closer to maximum brake torque spark advances and the reduced opening of the waste gate controlling the turbine, the E100 engine still have similar resistance to knock than the gasoline engine.

Variable valve actuation has been considered only for throttle-less load control to reduce the efficiency penalties reducing the load. Brake efficiencies larger than those of today's naturally aspirated gasoline engines are obtained from $25 \%$ of full load over the full range of engine speed. The variable valve actuation technology offers the potential of better charging efficiency over the range of engine speeds and loads, improved dynamic response, better combustion evolution, improved operation during catalyst light-off time.

When compared to a low tech $4 \mathrm{~L}$, throttle controlled, naturally aspirated gasoline engine to power a large Full size passenger car sedan, the small high tech turbo charged E100 engine with variable valve actuation use $43 \%$ less fuel energy over the NEDC.

The proposed results could help a move back by Original Equipment Manufacturer to vehicle powered by pure ethanol engines in markets like Brazil where ethanol is widely available with the embedded large advantages for economy, energy security and environment.

The key issue for small displacement, boosted, high compression ratio engines is how much engine downsizing can be achieved. The answer is government and community driven more than economically driven. Road safety rules and commitment to tackle climate change do not leave to much space for cheap naturally aspirated gasoline engines producing $300 \mathrm{~g} / \mathrm{km}$ of $\mathrm{CO}_{2}$ having power and torque outputs well in excess of what is allowed to use by speed limits. The proposed $1.6 \mathrm{~L}$ is the correct displacement for a high power density, turbocharged, directly injected engine with ethanol when motoring full size passenger cars, still providing large power margins for fun driving and climbing of hills or towing.

The compression ratio of 9:1 for the gasoline turbocharged direct injection engine originates from the high boosting. Higher compression ratios may follow the use of lower boosting. The compression ratio of 13:1 for the ethanol turbocharged direct injection engine is justified by the still better resistance to knock of the ethanol engine when compared to gasoline.

The small displacement engine use throttle-less load control enabled by fully variable valve lift to achieve close to Diesel driving cycle fuel efficiencies. The conventional throttled operation of a spark ignition engine is indeed the main reason of the poor fuel economy over driving cycles of these engines, much more than the penalty in top brake efficiencies. Variable valve actuation is effective in all the engines with load controlled by quantity of air and fuel introduced within the cylinder and not just fuel and larger engines may benefit more.

\section{REFERENCES}

1. http://www1.eere.energy.gov/biomass/ (retrieved January 13, 2010).

2. http://www.saabbiopower.co.uk/ (retrieved January 13, 2010).

3. Goto, O., et al., "Honda Formula One Turbo-charged V6 1.5L Engine", SAE P. 890877.

4. http://www.ae-plus.com/Technology\%20News/tn-INA-Uniair-june\%202006.htm (retrieved January 18, 2010).

5. D. Bradley, "Combustion and the design of future engine fuels", Proc. IMechE Vol. 223 Part C: J. Mechanical Engineering Science JMES1519. DOI: 10.1243/ 09544062JMES1519.

6. H. Takashi and T. Kimitoshi, "Laminar flame speeds of ethanol, n-heptane, isooctane air mixtures", Student Papers from FISITA 2006 world conference. FISITA F2006SC40. www.fisita.com/education/congress/sc06papers/f2006sc40.pdf (retrieved January 8, 2010).

7. L. Bromberg, D.R. Cohn, J.B. Heywood, "Calculations of knock suppression in highly turbocharged gasoline/ethanol engines using direct ethanol injection", MIT Laboratory for Energy and the Environment Report LFEE 2006-001. www.ethanolboost.com/LFEE-2006-01.pdf (retrieved January 14, 2010).

8. Brusstar, M., and Bakenhus, M., "Economical, high-efficiency engine technologies for alcohol fuels". http://www.epa.gov/otaq/presentations/epa-fev-isaf-no55.pdf (retrieved January 15, 2010).

9. West, B., "Enhanced Ethanol Engine And Vehicle Efficiency (Agreement 13425)", paper presented to the Energy 2008 Office of 
Vehicle Technologies Annual Merit Review Bethesda, Maryland, February 2008.

http://www1.eere.energy.gov/vehiclesandfuels/pdfs/merit_review_2008/fuels/merit08_west.pdf

10. Brewster, S., "Initial Development of a Turbo-charged Direct Injection E100 Combustion System", SAE P. 2007-01-3625. http://www.orbeng.com/orbital/tp/pdf/2007-01-3625.pdf (retrieved January 15, 2010).

11. Brewster, S., et al., "The Effect of E100 Water Content on High Load Performance of a Spray Guide Direct Injection Boosted Engine", SAE P. 2007-01-2648.

http://www.orbeng.com/orbital/tp/pdf/2007-01-2648.pdf (retrieved January 15, 2010).

12. Bromberg, L., "Benchmarking of Alcohol Chemical Kinetic Mechanism for Laminar Flame Speed Calculations", MIT Plasma Science and Fusion Center Report PSFC-JA-08-10. http://www.psfc.mit.edu/library1/catalog/reports/2000/08ja/08ja010/08ja010_full.pdf (retrieved March 2, 2010).

13. http://delphi.com/shared/pdf/ppd/pwrtrn/gas_multec_gdifsc.pdf

14. "Cold Start on the Transparent Engine: Ethanol Direct Injection in Turbo-Charged Spark-Ignited Engines", in AVL Combustion Measurement Newsletter Edition 2008: Combustion Analysis in Racing. http://www.avl.com/ (retrieved February 17, 2010).

15. Hakan Sandquist, Maria Karlsson, Ingemar Denbratt, "Influence of Ethanol Content in Gasoline on Speciated Emissions From a Direct-Injection Stratified Charge SI Engine", SAE P. 2001-01-1206.

16. Wei Zeng, Min Xu, Ming Zhang, Yuyin Zhang, David Cleary, "Characterization of Methanol and Ethanol Sprays from Different DI Injectors by Using Mie-Scattering and Laser Induced Fluorescence at Potential Engine Cold-Start Conditions", SAE P. 201001-0602.

17. Stina Hemdal, Jonas Warnberg, Ingemar Denbratt, Petter Dahlander , "Stratified Cold Start Sprays of Gasoline-Ethanol Blends", SAE P. 2009-01-1496.

18. Atsushi Matsumoto, Yi Zheng, Xing-Bin Xie, Ming-Chia Lai, Wayne R. Moore, Matthew Foster, Keith Confer, Eunjoo Hopkins, David Yen, "Spray Characterization of Ethanol Gasoline Blends and Comparison to a CFD Model for a Gasoline Direct Injector", SAE P. 2010-01-0601.

19. Stephan Liebsch, Oliver Dingel, Jochen Maass, Michael Guenther, Matthias Kratzsch, Steffen Zwahr, "Model Based E85 Cold Start Optimization for DISI Engines", SAE P. 2009-01-1909.

20. Craig D. Marriott, Matthew Wiles, J. Michael Gwidt, Scott E. Parrish, "Development of a Naturally Aspirated Spark Ignition Direct Injected Flex-Fuel Engine", SAE P. 2008-01-0319.

21. Paul E. Kapus, Alois Fuerhapter, H. Fuchs, Guenter K. Fraidl, "Ethanol Direct Injection on Turbocharged SI Engines - Potential and Challenges", SAE P. 2007-01-1408.

22. http://www.ricardo.com/en-gb/Software/Productoffering--description/WAVE1/ (retrieved January 8, 2010).

23. Douaud, A. M. and P. Eyzat. "Four-Octane-Number Method for Predicting the Anti-Knock Behavior of Fuels and Engines", SAE P. 780080

24. Blizard, Norman C., and James C. Keck. "Experimental and Theoretical Investigation of Turbulent Burning Model for Internal Combustion Engines", SAE P. 740191.

25. Hires, S. D., R. J. Tabaczynski, and J. M. Novak. "The Prediction of Ignition Delay and Combustion Intervals for a Homogeneous Charge, Spark Ignition Engine", SAE P.780232.

26. Tabaczynski, Rodney J., Frederick H. Trinker, and Ben A. S. Shannon. "Further Refinement and Validation of a Turbulent Flame Propagation Model for Spark-Ignition Engines". Combustion and Flame Vol. 39 (1980), pp. 111-121.

27. Morel, T., C. I. Rackmil, R. Keribar, and M. J. Jennings. "Model for Heat Transfer and Combustion in Spark Ignited Engines and Its Comparison with Experiments", SAE P. 880198.

28. Wahiduzzaman, Syed, Thomas Morel, and Stephen Sheard. "Comparison of Measured and Predicted Combustion Characteristics of a Four-Valve S.I. Engine", SAE P. 930613.

29. Morel, Thomas, and Rifat Keribar. "A Model for Predicting Spatially and Time Resolved Convective Heat Transfer in Bowl-InPiston Combustion Chambers", SAE P. 850204.

30. http://www.lesoft.co.uk/index1.html (retrieved January 20, 2010).

31. Robert S. Laramee, Daniel Weiskopf, Jurgen Schneider, Helwig Hauser, "Investigating Swirl and Tumble Flow with a Comparison of Visualization Techniques",

www.vrvis.at/publications/PB-VRVis-2004-038? set_language $=$ de (retrieved May 5, 2010).

32. http://www.audiworld.com/tech/eng80a.shtml (retrieved June 22, 2010).

33. http://www.rbracing-rsr.com/waterinjection.html (retrieved June 22, 2010).

34. http://www.afdc.energy.gov/afdc/progs/fuel_compare.php (retrieved June 22, 2010).

35. http://en.wikipedia.org/wiki/Octane_rating (retrieved June 22, 2010).

36. http://www.vcacarfueldata.org.uk/ (retrieved June 22, 2010). 